\title{
The interpretation of Mesolithic structures in Britain: new evidence from Criet Dubh, Isle of Mull, and alternative approaches to chronological analysis for inferring occupation tempos and settlement patterns
}

Article

Accepted Version

Mithen, S. and Wicks, K. (2018) The interpretation of Mesolithic structures in Britain: new evidence from Criet Dubh, Isle of Mull, and alternative approaches to chronological analysis for inferring occupation tempos and settlement patterns. Proceedings of the Prehistoric Society, 84. pp. 77110. ISSN 0079-797X doi: https://doi.org/10.1017/ppr.2018.13 Available at https://centaur.reading.ac.uk/77894/

It is advisable to refer to the publisher's version if you intend to cite from the work. See Guidance on citing.

To link to this article DOI: http://dx.doi.org/10.1017/ppr.2018.13

Publisher: Prehistoric Society 
copyright holders. Terms and conditions for use of this material are defined in the End User Agreement.

\section{www.reading.ac.uk/centaur}

\section{CentAUR}

Central Archive at the University of Reading

Reading's research outputs online 


\title{
The interpretation of Mesolithic structures in Britain: new evidence from Criet Dubh, Isle of Mull, and alternative approaches to chronological analysis for inferring occupation tempos and settlement patterns
}

\author{
STEVEN MITHEN AND KAREN WICKS \\ With a contribution from Anne Pirie
}

The number of Mesolithic structures known in Britain has significantly increased since 2000, providing new opportunities for economic and social interpretations of this period. We describe a further structure, represented by features from the Mesolithic site of Criet Dubh, Isle of Mull. We compare the inferred Criet Dubh structure to other Mesolithic structures from Britain, notably those described by Waddington \& Bonsall (2016) as 'pit-houses'. We then consider the implications of the radiocarbon dates from such structures for the temp of occupation and past settlement patterns. While the use of Bayesian analysis of radiocarbon dates has encouraged interpretations of prolonged occupation and sedentism, we propose alternative interpretations with patterns of intermittent occupation for Criet Dubh and the pit-houses, involving their re-use of after extended periods of abandonment within a sparsely populated landscape. The ability to debate such interpretations reflects the transformation in Mesolithic research made possible by the discovery of such structures, the use of multiple radiocarbon determinations, the application of Bayesian analysis, and the exploration of associations between cultural and environmental change. These developments have made the Mesolithic a particularly innovative period of study.

\section{KEYWORDS:}

Mesolithic structures, Occupation tempos, population densities, settlement patterns

\section{INTRODUCTION}

The number of known structures in the British Mesolithic has significantly increased during the last decade. This has enabled new interpretations of settlement patterns, some of which challenge conventional views of this period by promoting notions of hunter-gatherer sedentism. Nevertheless, the corpus of such structures remains limited and the interpretation of archaeological features remains challenging. In this contribution we report on a cluster of features from the Mesolithic site of Criet Dubh, Isle of Mull, and compare them to previously reported evidence in Britain to identify what type of structure they might represent. To do so, we initially follow Waddington \& 
Bonsall's $(2016,267)$ identification of a suite of British Mesolithic structures as 'pit-houses' and contrast these with what appear to be less substantial structures, referring to the latter as 'shelters'. We ask whether the inferred Criet Dubh structure supports or challenges this two-fold division. We then consider the radiocarbon dates from Criet Dubh and those Mesolithic structures categorized as pit-houses, contrasting two methods of analysis: those based on occupation spans as derived

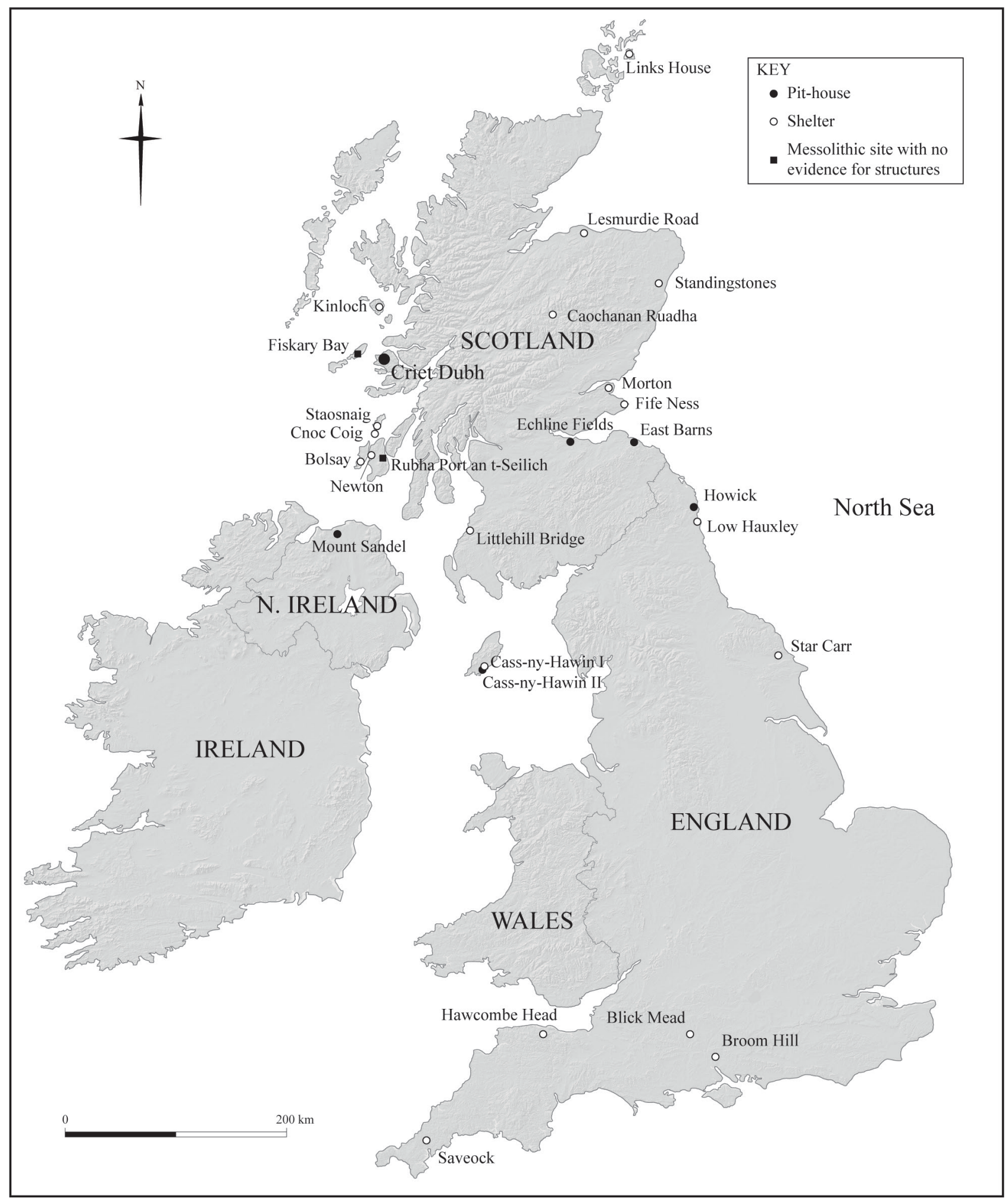

Figure 1. Location map showing Mesolithic sites referred to in the text 
from Bayesian analysis and those based on activity events as derived from the extent of statistical consistency between radiocarbon dates. We note how these imply different tempos of occupation for structures and different interpretations for Mesolithic settlement patterns.

\section{HUNTER-GATHERER STRUCTURES AND SETTLEMENT PATTERNS}

Lewis Binford (1990) argued that hunter-gatherer settlements are rarely without some form of artificial shelter. Fretheim (2017), reviewing a range of ethnographic studies as part of a comprehensive study of Mesolithic dwellings in Norway, agreed and noted their considerable diversity ranging from insubstantial huts to pit-houses, and from stand-alone structures to extensive settlements. The size, internal organization, form and number of structures can indicate past settlement patterns, group size and social organization, with a general correlation between the extent of labour investment and the degree of residential mobility (Fretheim 2017; Fretheim et al. 2016, 2018; Binford 1990; Kelly 1992). Nevertheless, the relationships between structures and behavior are not straightforward: even the most substantial dwelling might be used on an intermittent or seasonal basis. Moreover, before addressing questions of settlement pattern, archaeologists face the challenge of inferring what type of structure might have once been present from its residual material traces, such as stakeholes, post-holes, hearths and discrete distributions of occupation debris.

\section{MESOLITHIC STRUCTURES IN BRITAIN}

During the 1970s traces of structures were excavated at two Mesolithic sites in Britain, Mount Sandel, Northern Ireland (Woodman 1985) and Broom Hill, Hampshire (Selkirk 1978; O’Malley \& Jacobi 1978). Both provide a suite of stakeholes, post-holes and pits in sub-circular arrangements surrounding floor deposits, suggesting substantial structures (Table 1). That at Mount Sandel has since been categorized as a 'pit-house' (Waddington \& Bonsall 2016, 216), while the type of structure represented by the features at Broom Hill remains unclear (Gooder 2007; Bayliss \& Woodman 2009); we suspect it was less substantial than that at Mount Sandel and refer to Broom Hill as a 'shelter'. Further structures have since been discovered, some appearing less substantial than those at Broom Hill and Mount Sandel and others providing further examples of the proposed 'pit-house' category (Figure 1; Table 1).

In addition to pit-houses and shelters, two further categories of structure have been discovered. Wooden platforms and possible track ways are known from Star Carr, despite the platform originally proposed by Clark (1954) being an accumulation of debris rather than a deliberate construction (Mellars et al. 1998; Bamforth et al. 2018). These have been comprehensively discussed by Bamforth et al. and will receive no further consideration. Also excluded is the evidence for probable monumental structures, notably the Mesolithic pit alignments at Warren Field, Aberdeenshire (Gaffney et al. 2013) and at Stonehenge (Cleal et al. 1994, 43-56). Both appear to have been for substantial posts. While such wooden platforms and pit alignments are 
evidently crucial to a full understanding of the Mesolithic, our study will be restricted to the more extensive evidence for shelters and pit-houses.

\section{Shelters}

The term 'shelters' has been adopted to avoid implying that such structures were necessarily for human occupation; this category encompasses racks, storage contraptions, supports for cooking devices, windbreaks, tents, huts and composite structures (a combination of portable and stationary elements, Cribb 1991). These might involve minimal alterations or additions to natural features such as rock overhangs, boulders or trees, with the boundary between the artificial and the natural being problematic (Ingold 2000). The remains of probable shelters are now known from numerous Mesolithic sites, with a sample of illustrated in Table 1: Broom Hill (Selkirk 1978; O’Malley \& Jacobi 1978); Cass-ny-Hawin I, Isle of Man (Woodman 1987), Staosniag (Mithen et al. 2001), Lesmurdie Road, Elgin (Suddaby 2007), Star Carr (Conneller et al. 2012, now referred to as the 'eastern structure', Taylor et al. 2018, 63-65) and Low Hauxley, Occupation 2, Northumberland (Waddington \& Bonsall 2016).

The excavators are appropriately cautious when making their interpretations of the features at these sites: a 'light windbreak" or a hollow sheltered by an angled roof at Cass-ny-Hawin I (Woodman 1985, 18); a structure that was "a place of intense activity" at Star Carr (Conneller et al. 2012, 1012); "a light timber frame with tent or other lightweight covering ...of impermanent construction" at Low Hauxley (Waddington \& Bonsall 2016, 267), and no more than "post-circles" at Elgin (Suddaby 2007).

Additional sites with features and artefact distributions implying shelters are found throughout Britain. Those in Scotland include: arcs of stakeholes from Cnoc Coig (Isle of Oronsay, Mellars 1987); a sunken sub-rectangular area at Newton (Isle of Islay, McCullagh 1989); oval scoops from Littlehill Bridge (Ayrshire, MacGregor et al. 2010); stake-holes, post-holes and pits from Morton (Fife, Coles 1971), Kinloch (Isle of Rum, Wickham-Jones 1990), Fife Ness (Fife, WickhamJones \& Dalland 1998), and Bolsay (Isle of Islay, Mithen et al. 2000); and constrained artefact distributions from Caochanan Ruadha (southern Cairngorms, Warren et al. 2018). A cluster of stake and post holes, scoops, pits and shallow hollows interpreted as a several 2-3m diameter Mesolithic structures and a windbreak have recently been excavated at Links House, Orkney (Lee and Woodward, forthcoming). At Standingstones, $13 \mathrm{Km}$ to north of the River Dee, an arc of eight pits enclosing an area of $3 \mathrm{~m}$ diameter containing a central hollow(hearth?), has been interpreted as the remains of a Mesolithic structure within a 'short-lived camp' (Dingwall, pers comm).

Evidence for Mesolithic shelters from England include a green clay floor surrounded by stakeholes at Savelock, (Cornwall, Wood 2007), post-holes and a clay floor from Hawkcombe Head (Somerset, Gardiner 2007 a 'gully defined structure' designated as Occupation 1 at Low Hauxley (Northumberland, Waddington \& Bonsall 2016), and a modified tree-throw from Blick Mead in the 
vicinity of Stonehenge that might have been used as a shelter (Jacques et al. 2017),. In addition to the eastern structure from Star Carr, illustrated in Table 1, three further clusters of shallow postholes have been identified, referred to as the western, central and northern structures (Taylor et al. 2018). The central structure is the most substantial but is still relatively ephemeral when compared to the pit-houses, with a shallow hollow, c. $3.0 \mathrm{~m}$ by $2.5 \mathrm{~m}$, surrounded by postholes. The northern structure consists of two arcs of postholes and the western structure is a cluster of postholes that might derive from a hut, a raised storage area or a drying rack (Taylor et al. 2018, 59). In addition to these putative structures, there are further isolated postholes and pits at Star Carr, some or all of which might relate to past shelters. At Mount Sandel, Northern Ireland, an arc of stake holes and gullies to the north of the main cluster of post-holes, pits and hearths are likely to derive from a light shelter, which might come from a later period of activity at the site (Woodman 1985).

Quite what types of shelters such features from Mesolithic sites represent, if any, remain unclear in all cases. There are numerous methodological problems with their interpretation, which are shared with the pit-houses described below. These include:

Contemporaneity: the difficulty of being confident about which features derive from the same structure and whether the debris contained within a floor represents the primary or a secondary use of the structure;

Preservation: features such as stakeholes and post-holes might be truncated or removed entirely by later human activity, natural erosion, or soil development such as podsolization. This constrains assessing their number, dimensions and depth, and hence the scale of the structure that might have been supported by the surviving evidence;

Equifinality: substantial structures might leave no archaeological traces or those identical to light shelters. Tents, for instance, might be either archaeologically invisible or leave highly ambiguous features while providing substantially larger and more robust shelters than small huts that leave an impressive pattern of stake- and post-holes.

Absolute dating is also problematic partly because of the limited number of radiocarbon determinations available from the sites that have ephemeral deposits. Cass-ny-Hawin I has no directly associated radiocarbon dates, and there are just two from each post-hole circle at Elgin (Table 1). The eight radiocarbon dates from the fill of the main feature (F24) at Staosnaig indicate predominant activity between c. 6800-5880 cal BC (with earlier and later episodes) but these might derive from a secondary use of the structure (Mithen et al. 2001). That might also be the case for Occupation 2 at Low Hauxley that has four radiocarbon dates on samples from within its fill suggesting activity between c. 7990-7610 cal BC (Hamilton 2016). Conversely, the dating of the post-holes at Lesmurdie Road is problematic because the charcoal contained within their fills might have been re-deposited from earlier activity at the site unrelated to the structure represented by post-holes (Suddaby 2007). The eastern and western structures at Star Carr are dated by multiple 
Table 1: A sample of shelters and pit-houses from the British Mesolithic

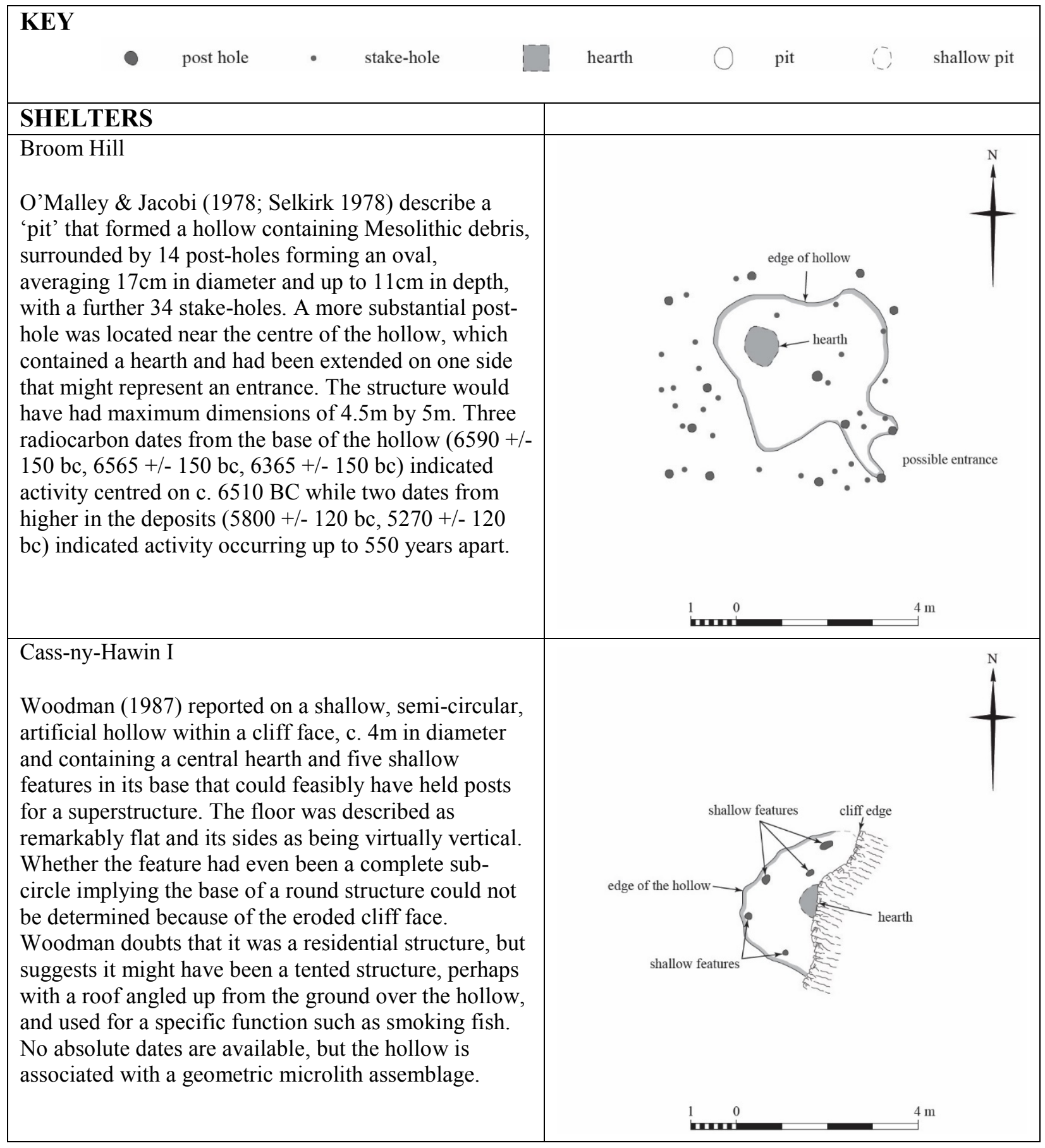




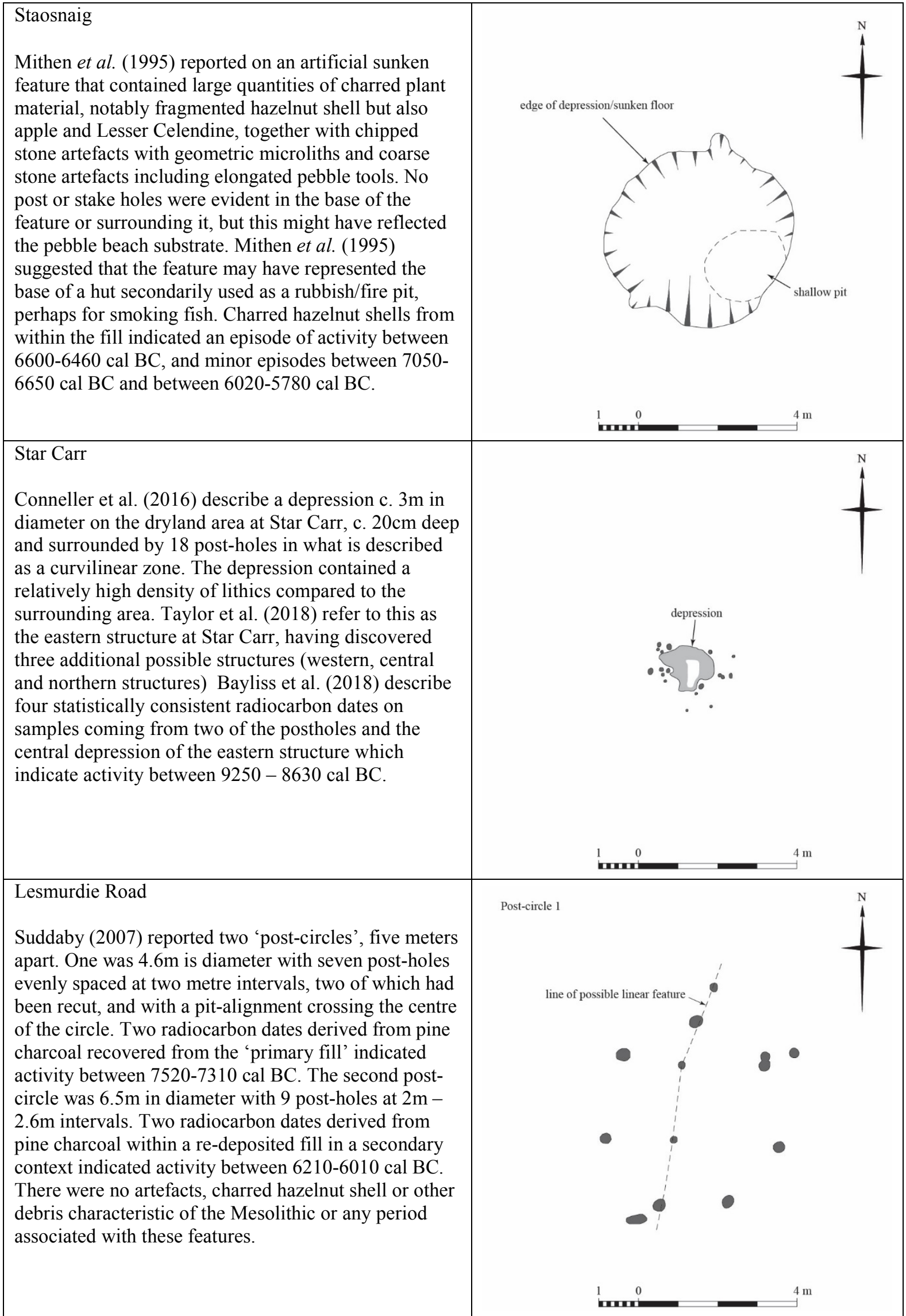




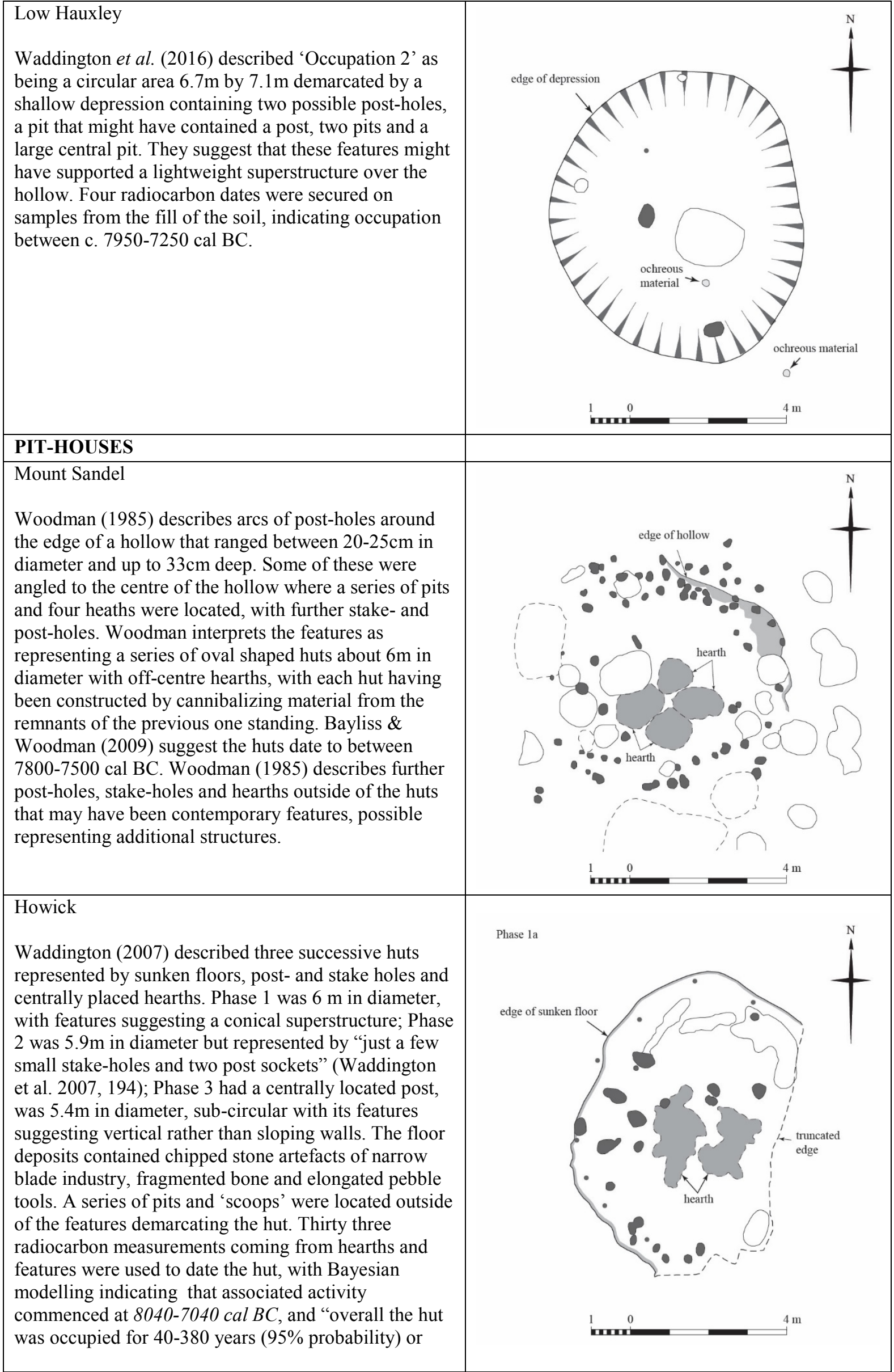




\begin{tabular}{|c|c|}
\hline $\begin{array}{l}\text { 100-300 years ( } 68 \% \text { probability" (Bayliss et al. 2007, } \\
71) .\end{array}$ & \\
\hline $\begin{array}{l}\text { East Barns } \\
\text { Gooder (2007) describes a sub-circular sunken floor } \\
6.8 \mathrm{~m} \text { N-S by } 6.2 \mathrm{~m} \text { E-W which contained } 30 \text { post-holes } \\
\text { varying in size between } 0.25-0.5 \mathrm{~m} \text { in width and up to } \\
0.6 \mathrm{~m} \text { deep, with the majority tilted towards the centre. } \\
\text { A number of these were sealed by a burnt organic rich } \\
\text { deposit, interpreted as a collapsed wall. A possible } \\
\text { hearth was positioned centrally with a floor area of } \\
5.8 \mathrm{~m} \text { N-S and } 5 \mathrm{~m} \text { E-W. Three samples of charred } \\
\text { hazelnut shell coming from the fill of a post-hole sealed } \\
\text { by the probably collapsed wall indicated a date of c, } \\
8000 \text { cal BC. The structure was surrounded by } \\
\text { occupation debris of chipped stone artefacts of narrow } \\
\text { blade industry, charred hazelnut shell and a small } \\
\text { quantity of animal bone, but such anthropic deposits } \\
\text { were absent from the interior of the structure which } \\
\text { Gooder describes as "perplexing" (2007, } 55 \text { ). }\end{array}$ & Possible entrance \\
\hline $\begin{array}{l}\text { Echline Field } \\
\text { Robertson et al. (2013) describe a sub-circular sunken } \\
\text { floor } 6.96 \mathrm{~m} \text { by } 5.92 \mathrm{~m} \text { in diameter, } 0.5 \mathrm{~m} \text { deep with an } \\
\text { outer-ring of nine post-holes between } 0.3 \mathrm{~m} \text { and } 0.7 \mathrm{~m} \text { in } \\
\text { diameter and up to } 0.3 \mathrm{~m} \text { deep. A possible west-facing } \\
\text { entrance was demarcated by two of the post-holes. A } \\
\text { second ring of six post-holes formed an oval } \\
\text { arrangements within the interior, } 2.9 \mathrm{~m} \text { by } 2.15 \mathrm{~m} \text {. } \\
\text { Twenty-one features were found close to the centre of } \\
\text { the structure, some of which were interpreted as hearths } \\
\text { and refuse pits; patches of burnt clay might have been } \\
\text { daub from the walls. The features were sealed by an } \\
\text { occupation deposit containing chipped stone, fragments } \\
\text { of bones and charred hazelnut shell. Seven radiocarbon } \\
\text { dates were secured, two from charred hazelnut shell } \\
\text { from within post-holes and five from the occupation } \\
\text { deposit with four of these on charred hazelnut shell } \\
\text { fragment and one on bone. These indicated three } \\
\text { periods of activity centred on } 8290,7250 \text { and } 7080 \text { cal } \\
\text { BC. }\end{array}$ & hearth \\
\hline
\end{tabular}



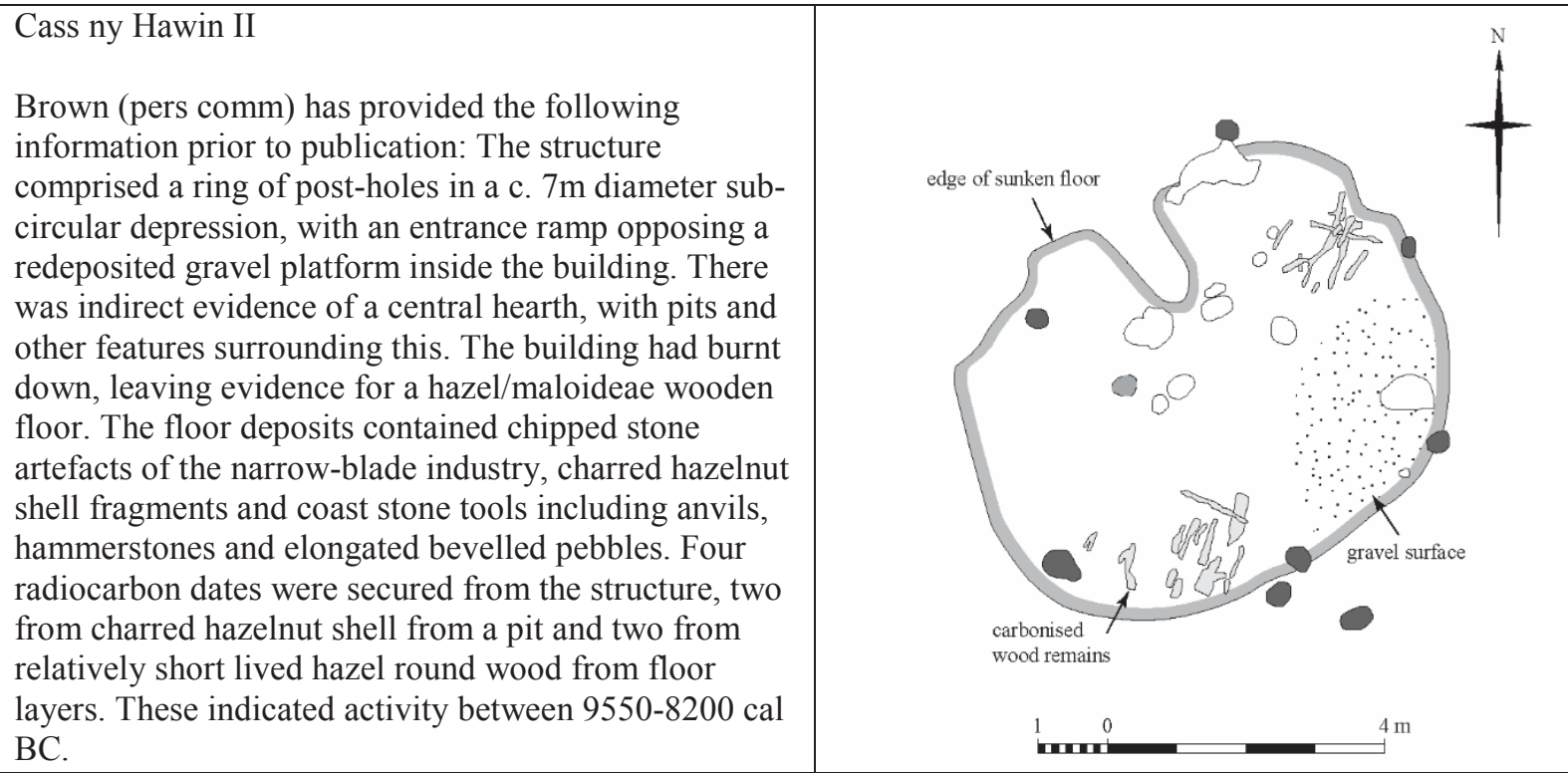

and statistically consistent radiocarbon samples from secure contexts to between 9260-8625 cal $\mathrm{BC}$, while the central structure has a dispersed range of dates suggesting that its features have a disturbed formation history (Bayliss et al. 2018). The Standingstones structure has been dated to approximately 7000-6700 cal BC (Dingwall, pers comm). Despite the limited and ambiguous dating evidence from the shelters in Table 1 and the other sites referred to above, the range of dates available and/or their relative dating based on associations with both early and later Mesolithic artefacts, suggest shelters are found throughout the entire span of the Mesolithic. Indeed, we suspect that shelters were ubiquitous at Mesolithic settlements.

\section{Pit-houses}

The shelters from Mesolithic Britain have been contrasted with a number of more substantial structures, described by Waddington \& Bonsall $(2016,216)$ as 'pit-houses' as listed in Table 1: Mount Sandel (Northern Ireland, Woodman 1985; Bayliss \& Woodman 2009); Howick (Northumberland, Waddington 2007), East Barns (East Lothian, Gooder 2007); Echline Fields (South Queensferry, Robertson et al. 2013), and Cass-ny-Hawin II (Isle of Man), which remains unpublished (Brown pers comm).

The term 'pit-house' was adopted from Norwegian terminology where it is used to describe structures with sunken floors and robust timber supports (Waddington \& Bonsall 2016, 266; Bjerck 2007, 2008; Fretheim et al. 2016, 2018; Fretheim 2017). Appearing in the early part of the Norwegian Middle Mesolithic (8000-7000 cal BC) pit-houses are recognized as the oldest unambiguous houses in Norway, with 'house' being defined as a structure designed to withstand local ambient conditions during all seasons, even if only occupied for a few weeks each year. While Britain can now boast to having potentially five pit-houses, there are perhaps over 100 in Norway, often found in small groups (3-4) and sometimes in larger clusters $(>10)$, with a similar number of other types of structures (Frethiem 2017). 
The term 'pit-house' is problematic on various grounds, especially for the British examples. The word 'house' implies a range of domestic activities including sleeping, cooking, easting, socializing and child-care, whereas some or all of these structures might have been for specialized functions, such as smoking fish or ritual activities. Equally, they might have changed their functions over time, either temporarily within the course of an annual settlement pattern, as described by Binford (1982) for the Nunamiut, or more permanently over a longer period of time: on some occasions used for domestic activities and at others for hunting or fishing camps.

In light of these caveats, the term 'pit-house' is most appropriately used as a descriptive rather than an interpretative label. In this regard it captures significant similarities between the Mount Sandel, Howick, East Barns and Echline Fields structures. These are all circular, c. $6 \mathrm{~m}$ in diameter with sunken floors and have a combination of post-holes, stake holes and hearths (Table 1); only the phase 3 structure at Howick has a central post, this also being anomalous by having a subrectangular form. The better preserved - Howick and Mount Sandel - suggest multiple re-builds on the same footprint. These pit-houses appear to be stand-alone structures rather than parts of multi-pit-house settlements. This might, however, reflect the limited extent of excavation and/ or preservation. Surrounding structures might have been less substantial, falling into our category of shelters that includes storage and drying racks. Such shelters might be represented by the occupation horizon around the periphery of East Barns (Gooder 2007), and the range of features outside of the hut/pit-house area at Mount Sandel (Woodman 1985), while a number of structures smaller than the pit-house have been recorded at Echline Fields (Robertson et al. 2013).

With regard to chronology, Bayliss \& Woodman $(2009,121)$ note that Mount Sandel, Howick and East Barns were all built during one short period of time between c. 8000-7600 cal BC referring to this as a "curious aspect of the settlement archaeology of the British Isles". The hut at Echline extends this period by having a date of c. $8300 \mathrm{cal} \mathrm{BC}$ leading Robertson et al. (2013) to invoke a 'house horizon', while the pit-house from Cass-ny-Hawin II is similarly dated to 8200-7950 cal BC (Brown pers comm).

Waddington et al. $(2007,207)$ suggest this limited chronological range for pit-houses derives from a "particular response to a specific set of historical, social, economic and environmental circumstances" - namely sea level rise and a secondary colonization of Britain as documented by the appearance of Narrow Blade industry with its preponderance for geometric microliths. Waddington associates the pit-houses with the appearance of the Narrow Blade industry and a predominantly coastal exploitation pattern by a newly arriving population, viewing these as three elements of a cultural package: pit-houses, geometric microliths, and coastal adaptation (Waddington 2015; Waddington \& Bonsall 2016). He contrasts this with a proposed terrestrialfocused lifestyle for the pre-existing Mesolithic population in Britain associated with a the Broad Blade industry, as represented at Star Carr. 


\section{CRIET DUBH, ISLE OF MULL}

\section{Discovery and excavation}

Criet Dubh is the name of a modern house situated c. $500 \mathrm{~m}$ from the southwest side of Loch a' Chumhainn estuary on the Isle of Mull, western Scotland (NGR: NM40923 753118) (Figures 2 and 3 ), and adjacent to a small burn. The archaeological site is located to its immediate north, between two linear outcrops of rock that enclose Criet Dubh's sheltered garden. Chipped stone was exposed in 2000 while the garden was being cultivated, and inspected by the authors in November 2005.

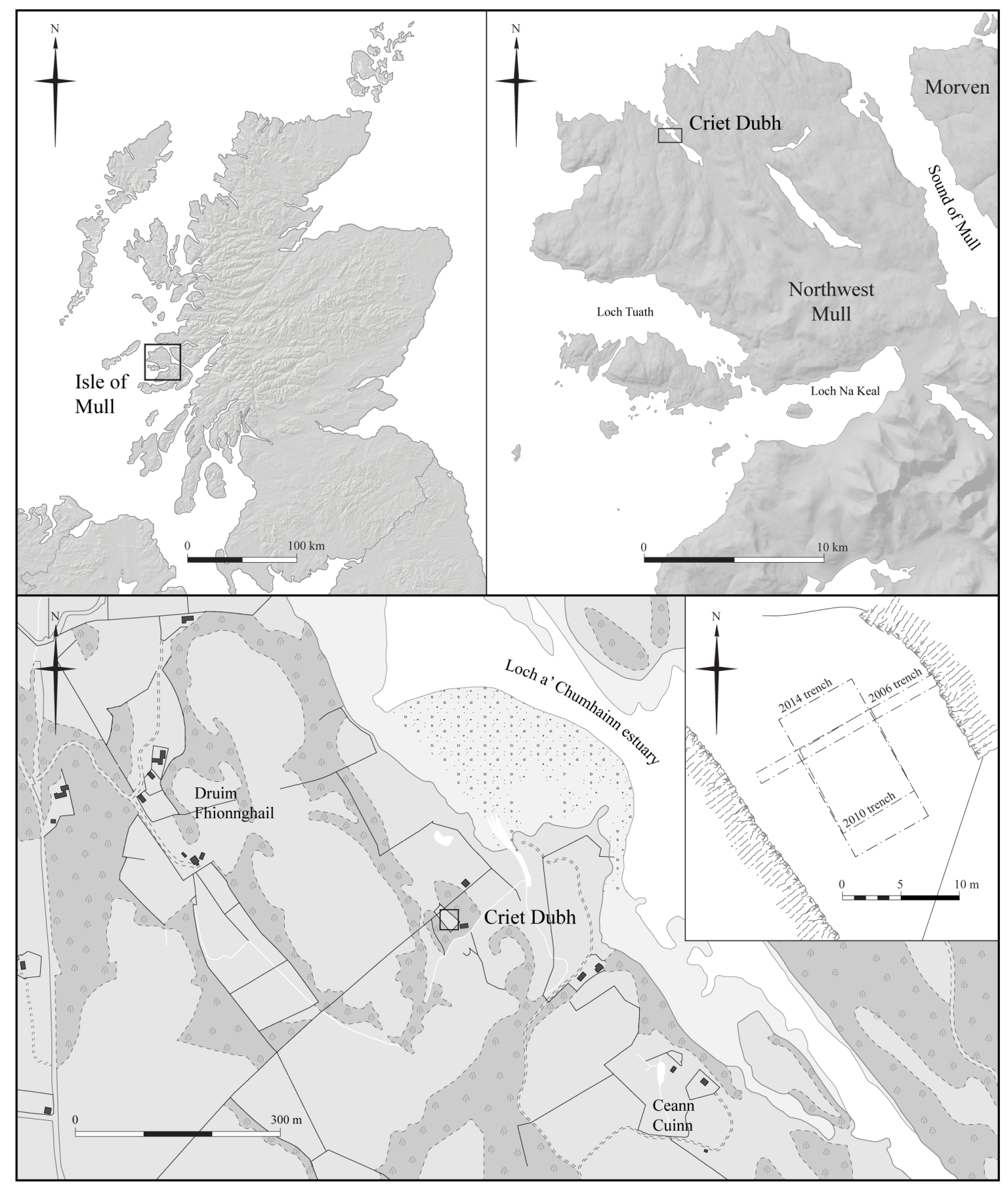

Figure 2: Map showing the location of Criet Dubh situated within a few hundred metres of the western shore of Loch a' Chummhain estuary in NW Mull, western Scotland, and plan of excavation showing 2006 trial trench, 2010 test trench and the 2014 excavation 
The artefacts were typical of the Mesolithic Narrow Blade industry as found elsewhere in western Scotland (Saville 2004; Mithen 2000), mixed with some later material including a barbed and tanged arrowhead.

A 2006 trial trench exposed a heavily cultivated soil containing chipped flint, glazed pottery and modern debris. Its removal exposed the fill of a feature $1.6 \mathrm{~m}$ wide that had been cut into a sterile weathered bedrock deposit. The feature (later designated as Feature 55) was sectioned to reveal several flat slabs that appeared to have been deliberately positioned and embedded within a greasy, black organic rich deposit. The full extent of the feature was not exposed and so whether it was the terminus of a linear ditch-like feature, a pit or a hearth, remained unclear. A fragment of charred hazelnut shell from its fill returned a date of 7830 \pm 80 BP (Beta-221402; Table 2).

Table 2: The interpretation of features from Criet Dubh

\begin{tabular}{|c|c|c|}
\hline Description & Features & Interpretation and figures \\
\hline $\begin{array}{l}\text { Amorphous spreads of fill containing } \\
\text { charcoal and chipped stone and burnt } \\
\text { slabs without any evident patterning }\end{array}$ & Features 1 and 70 & $\begin{array}{l}\text { 'Capping spreads': re- } \\
\text { deposited fill from features } \\
\text { arising from recent cultivation } \\
\text { activity in the garden }\end{array}$ \\
\hline $\begin{array}{l}\text { Circular and sub-circular features less } \\
\text { then }<0.2 \mathrm{~m} \text { in diameter, and of varying } \\
\text { depths }\end{array}$ & $\begin{array}{l}\text { Features } 13,14,15,17,20 \\
25,26,27,28,33,35,36 \\
44,48,49,51,57,60,61 \\
65,72,73,78,80,81,82\end{array}$ & $\begin{array}{l}\text { truncated stake-holes } \\
\text { Figure } 7\end{array}$ \\
\hline $\begin{array}{l}\text { Circular and sub-circular features }> \\
0.2 \mathrm{~m} \text { and }<0.5 \mathrm{~m} \text { in diameter, and of } \\
\text { varying depths }\end{array}$ & $\begin{array}{l}\text { Features } 2,3,4,5,6,9,10 \\
11,16,18,19,29,37,38 \\
40,41,45,46,67,74,75 \\
76\end{array}$ & $\begin{array}{l}\text { truncated post-holes } \\
\text { Figure } 8\end{array}$ \\
\hline $\begin{array}{l}\text { Circular and sub-circular features }> \\
0.5 \mathrm{~m} \text { in diameter, frequently containing } \\
\text { burnt stone and often inter-cutting each } \\
\text { other, but with poor definition }\end{array}$ & $\begin{array}{l}\text { Features } 7,8,23,24,30 \\
31,32,34,39,50,52,53 \\
54,55,58,59,68,69,71 \\
77,79,83\end{array}$ & $\begin{array}{l}\text { fire-pits } \\
\text { Figure } 9\end{array}$ \\
\hline $\begin{array}{l}\text { Sub-circular or amorphous features with } \\
\text { predominately sandy/silt fill }\end{array}$ & Features 47 and 56 & tree throws \\
\hline Straight-sided features & Features 21 and 22 & modern cultivation furrows \\
\hline
\end{tabular}

A 2010 exploratory excavation ( $7 \mathrm{~m} \times 7 \mathrm{~m})$ exposed an amorphous spread of greasy, organic and artifact rich black sediment (later designated as Feature 1, Figure 4), from which a charred twig (of indeterminate species) provided a date of $7900 \pm 40 \mathrm{BP}$ (Beta-288420). A number of discrete features were also exposed, the majority of which remained unexcavated (Mithen \& Wicks 2011; Wicks \& Mithen 2011). One feature, later designated as Feature 83, provided a charred hazelnut shell fragment dated to $9080 \pm 40$ BP (Beta-288421), (Table 2).

In 2014 the site became at risk from further cultivation. As a consequence, the suite of features was fully excavated within a $15 \mathrm{~m} \times 7 \mathrm{~m}$ trench. This demonstrated that the greasy spread (Feature 1) was an amalgam of the re-deposited fills from multiple underlying and surrounding features that had been heavily truncated by recent gardening activity. A second amorphous spread of re-deposited 


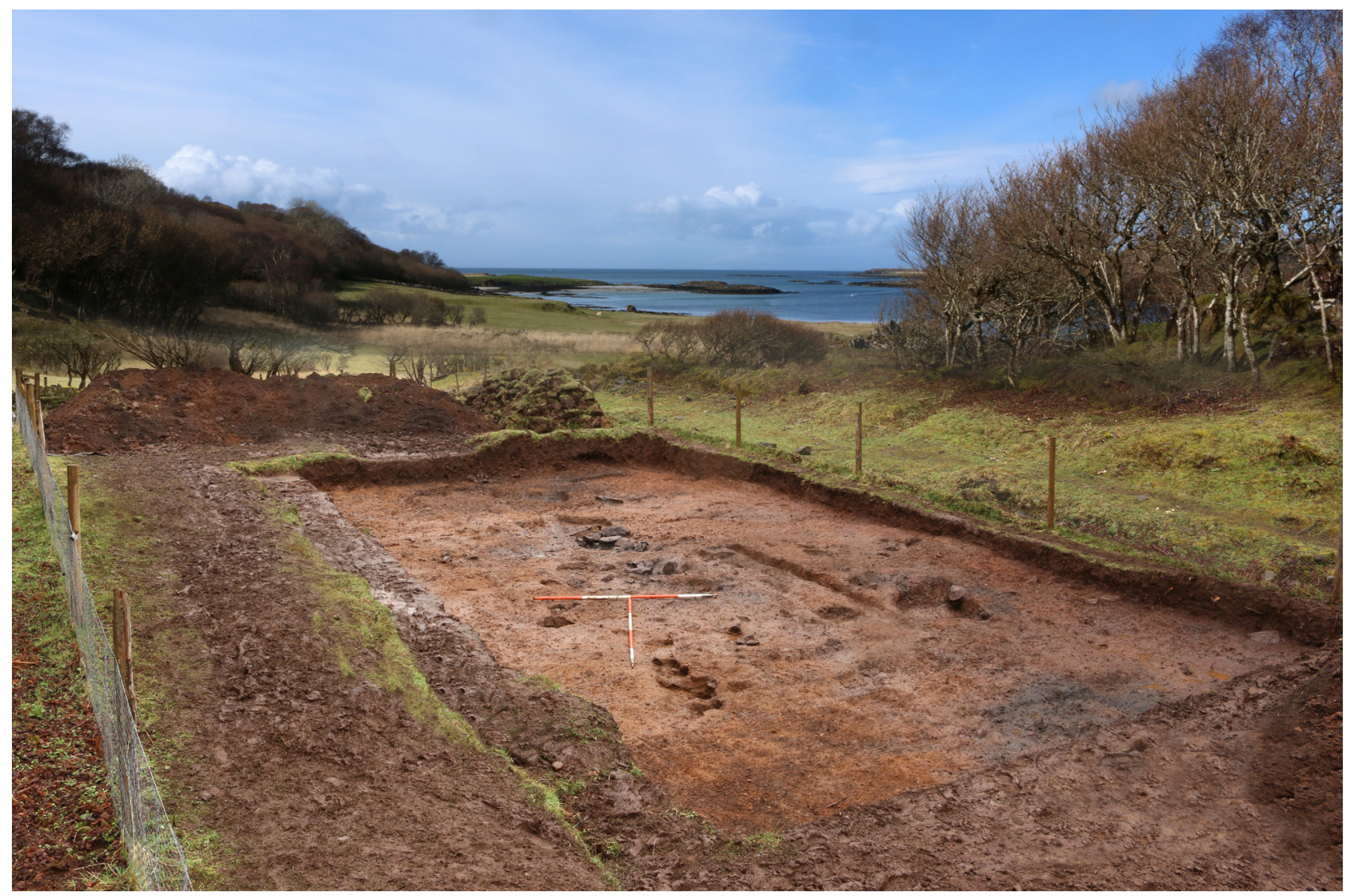

Figure 3: View of Criet Dubh Mesolithic site, looking north

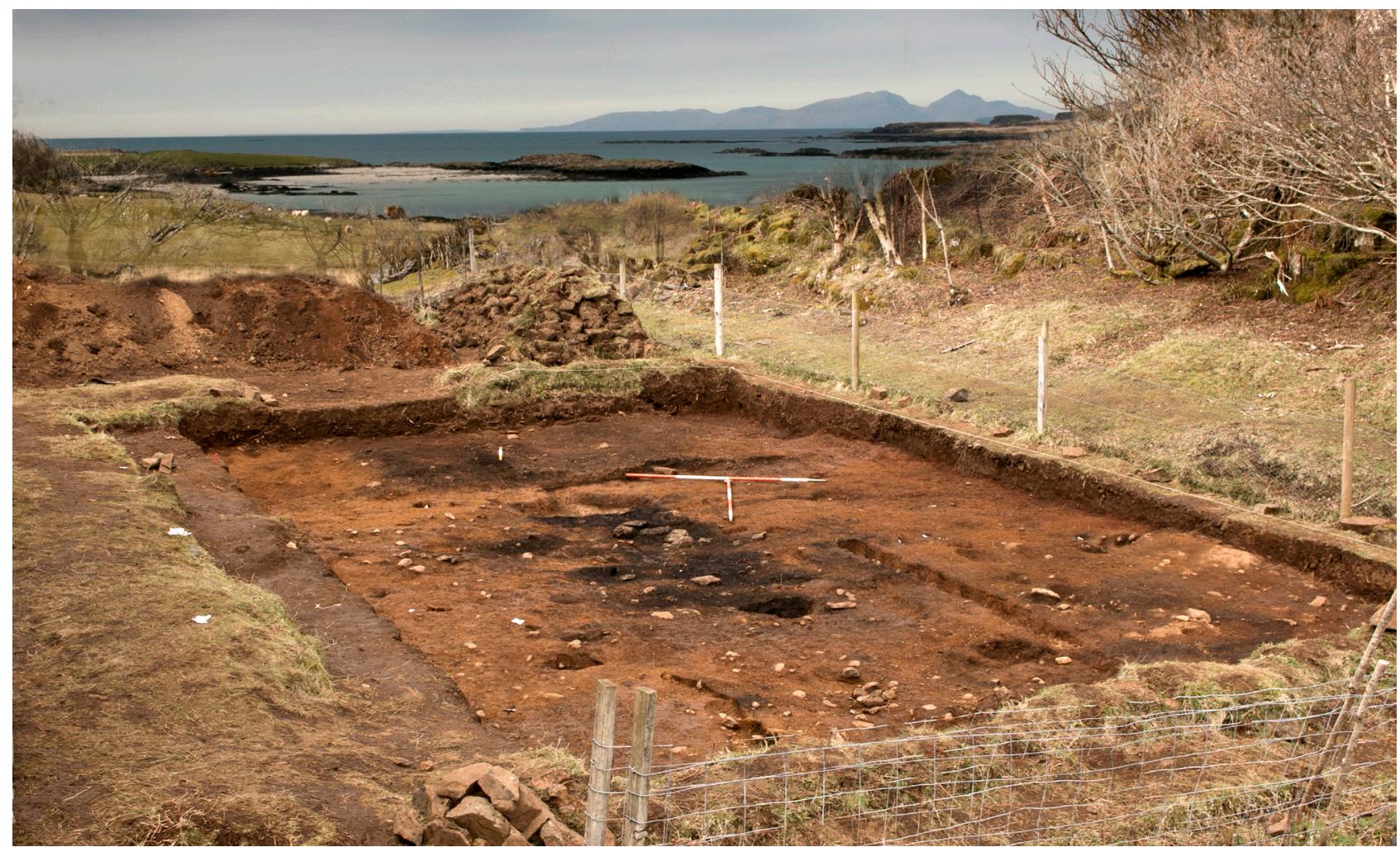

Figure 4: The 'capping spread' (Feature 1) that sealed the stone-lined fire-pits in the centre of the trench, looking north towards the Isles of Rum, Muck and Eigg 


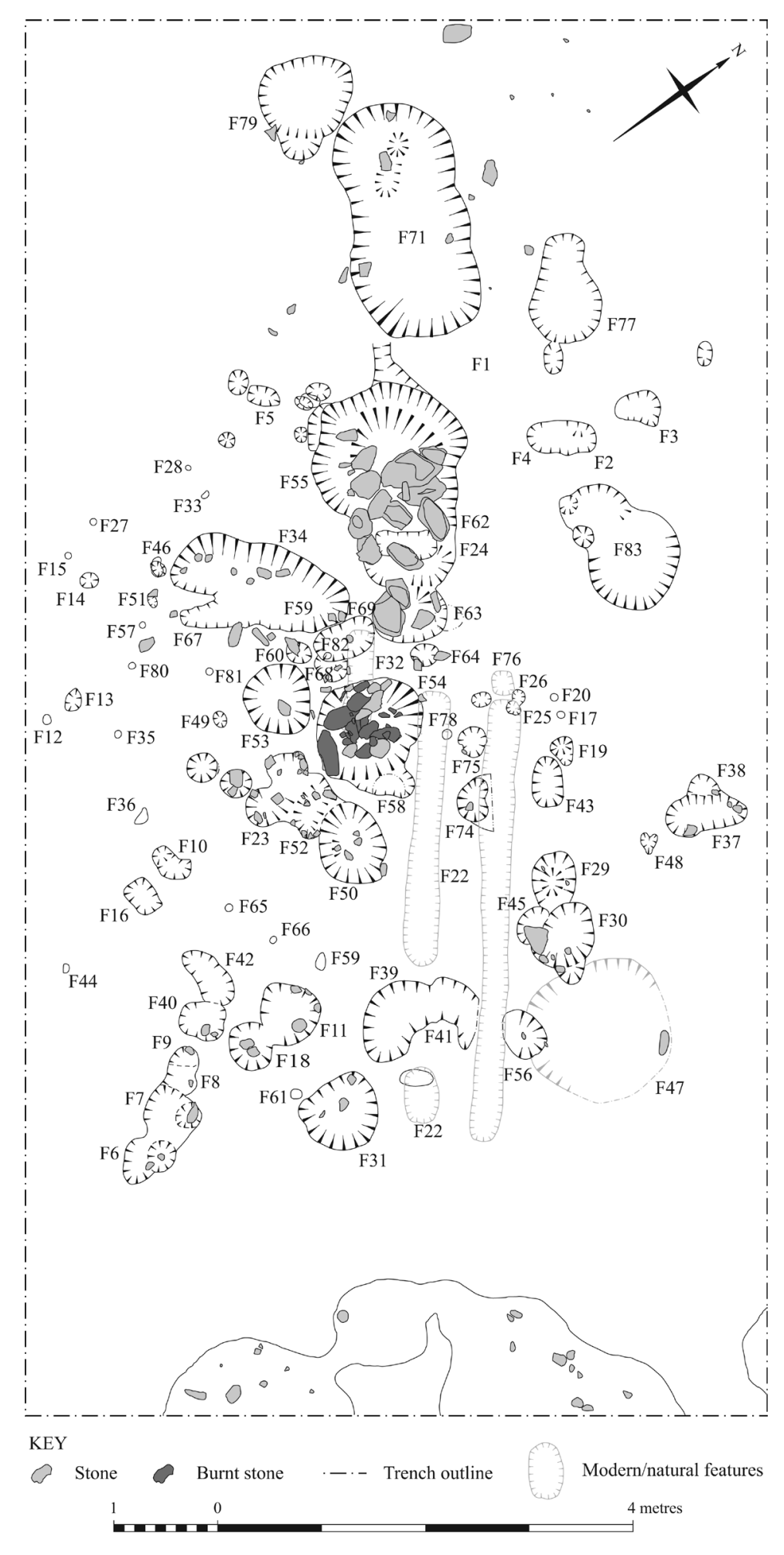

Figure 5: Distribution of features at Criet Dubh below and around the 'capping spreads (Features 1 and 70$)$ 

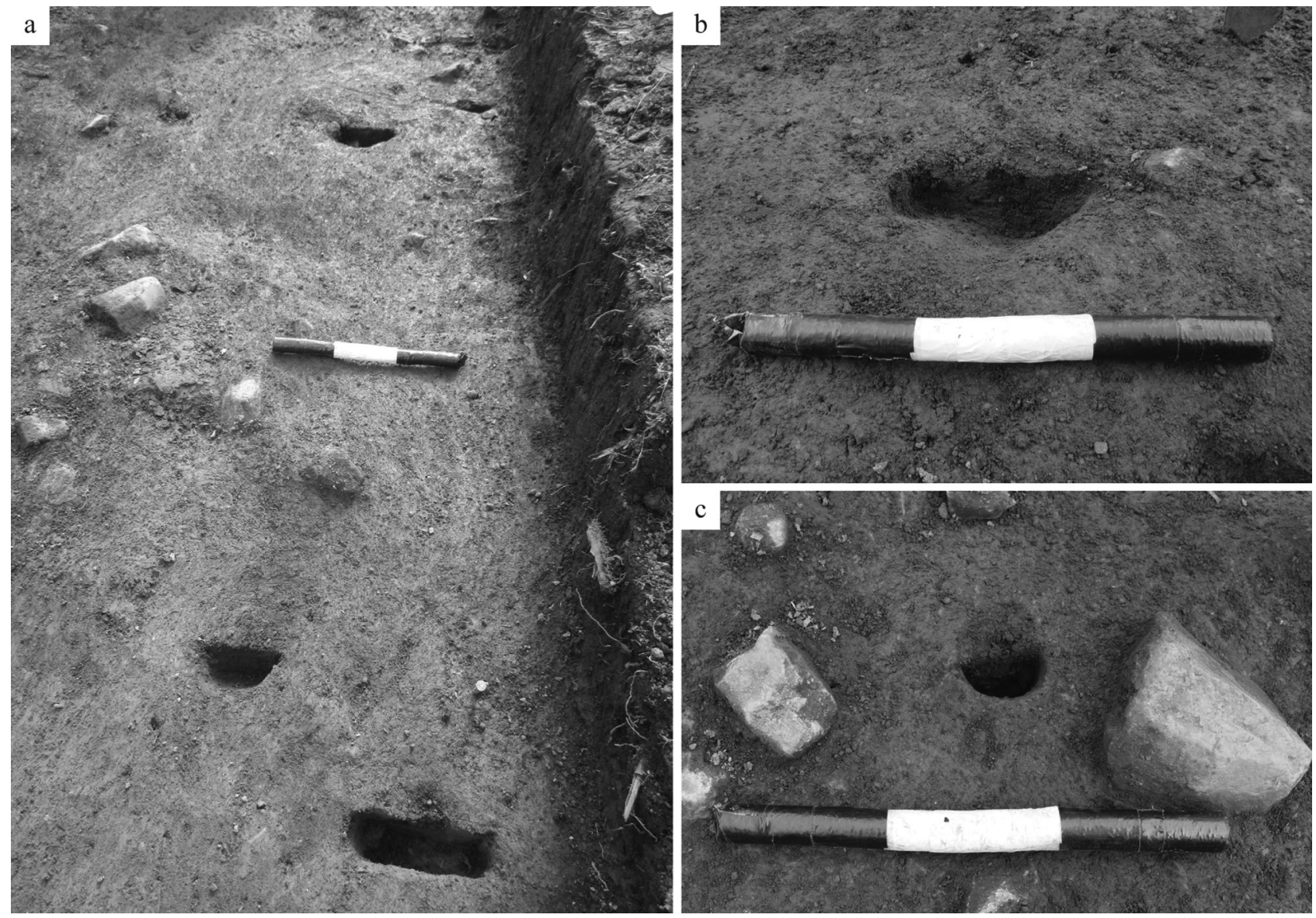

Figure 6: A sample of features interpreted as stake-holes: a) Features 12, 13, 14, 15; b) Features 25 and 26; C) Feature 57

fill was located at the northern end of the Trench (Feature 70), most likely a continuation of Feature 1 but separated by a baulk of the excavation.

Below and around these amorphous spreads eighty-one features of varying character were identified (Figure 5). The majority of these were filled with a similar organic rich, black greasy fill, often containing chipped stone artefacts and charcoal. The larger features contained stone slabs and rocks, some of which had been heavily burned and sometimes appeared to provide a lining to the feature. The majority of these larger features were in clusters with considerable but poorly defined inter-cutting, while the surrounding smaller features were isolated from each other. A classification system was devised according to the general shape, size and fill of the features,
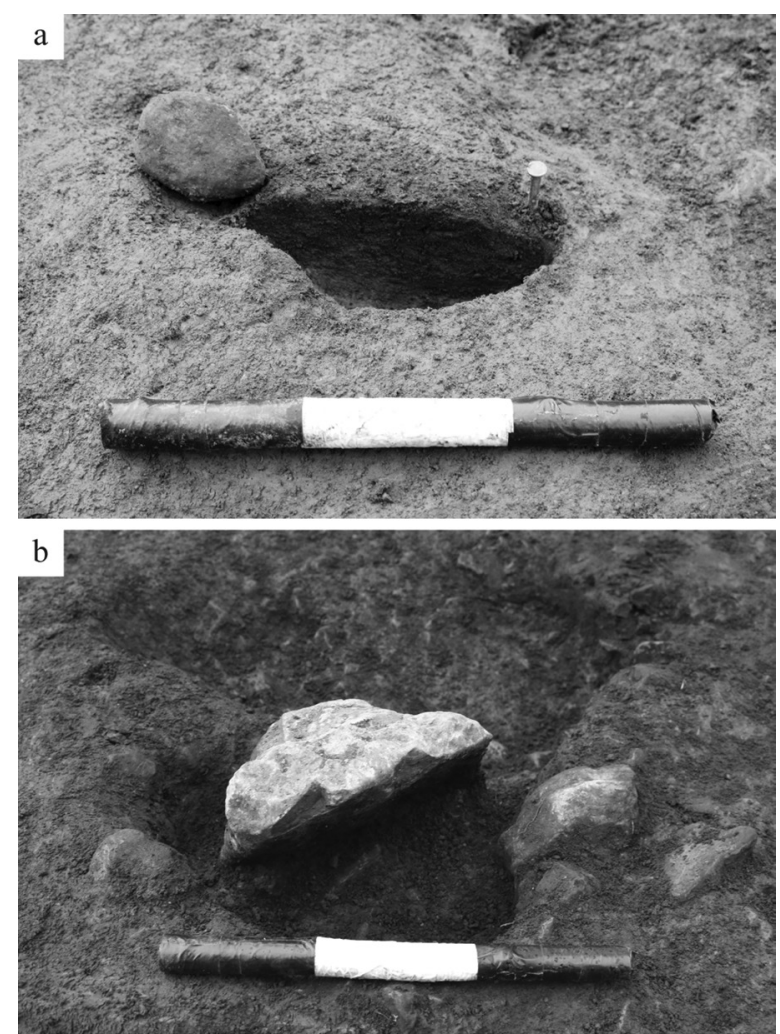

Figure 7: A sample of features interpreted as post-holes: a) Feature 46; b) Feature 45 
resulting in six broad categories with associated interpretations: capping spreads, stake holes (Figure 6), post-holes (Figure 7), fire pits (Figure 8), tree throws and modern cultivation furrows, (Table 2).

With the exception of the capping spreads (F1 and F70), a 100\% sample of the fill was removed from the majority of features, generating 68 bulk samples for wet sieving through a $3 \mathrm{~mm}$ mesh. Sieve residues were air-dried and sorted to recover flint and quartz artefacts, wood charcoal and charred hazelnut shell; bone was entirely absent. A 5\% sample of the sediment from Features 1 and 70 (the 'capping spreads') was processed in an identical manner.
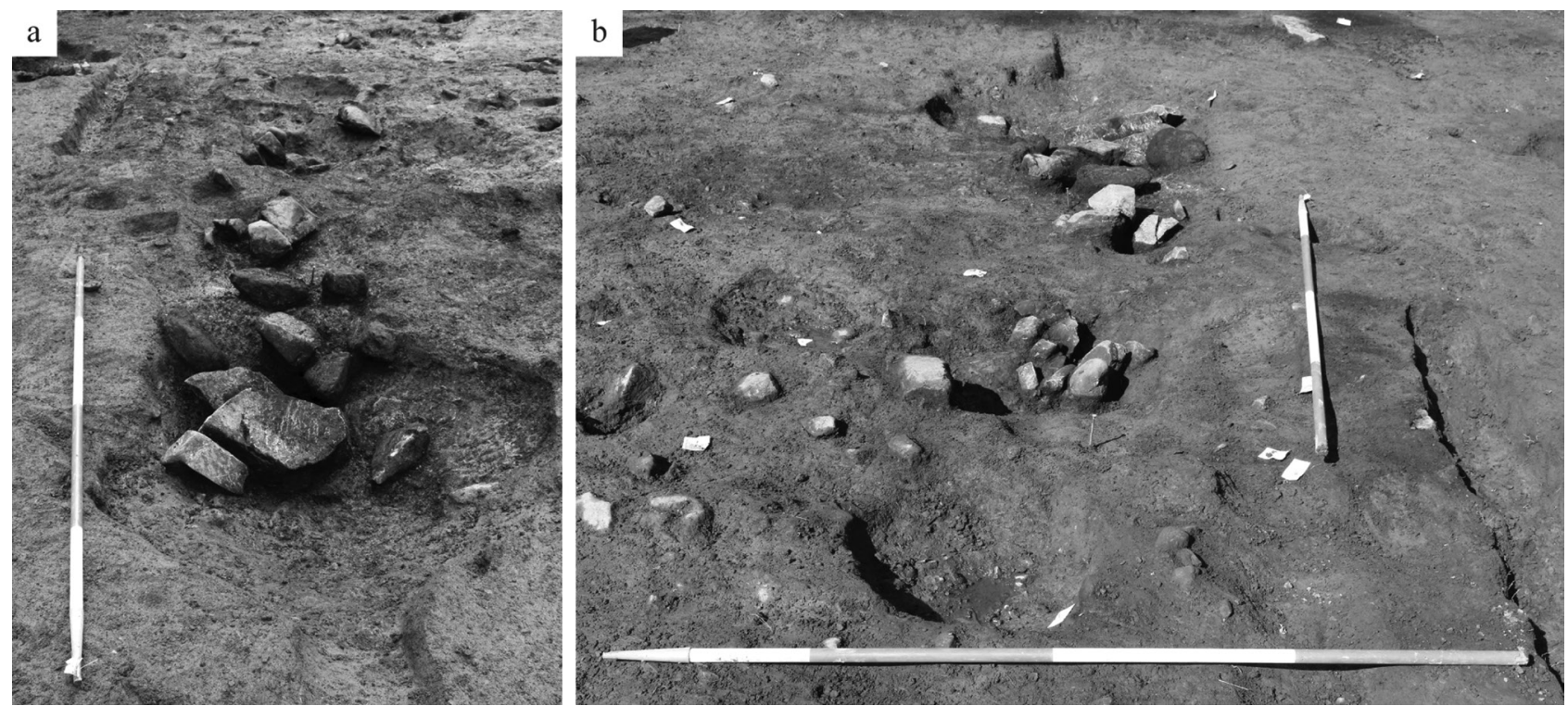

Figure 8: A sample of features interpreted as fire-pits: a) Feature 55 looking SE; b) Feature 63, 62, 55 looking $\mathrm{NW}$

\section{Associated artefacts, by Anne Pirie}

In striking contrast to other Mesolithic sites in the region, such as Staosnaig (Colonsay), Bolsay (Islay) and Rubha Port an t-Seilich (Islay) (Mithen 2000; Mithen et al. 2015), coarse stone artefacts such as spherical hammer-stones and elongated pebble tools were entirely absent from Criet Dubh. An assemblage of 2796 chipped stone artefacts predominantly on flint was collected during excavation in 2014 (Table 3), a sample of which is illustrated in Figure 9. Any surviving cortex suggested the use of beach pebbles as raw material. Burnt artefacts are frequent, resulting in large numbers of fragmentary indeterminate pieces $(51 \%)$. The assemblage has a predominance of flakes and very few cores, most of which are notably small (Table 4; Figure 9). Over half of the cores (55\%) are platform cores and a further $15 \%$ show mixed platform and bipolar reduction; only $25 \%$ are purely bipolar with no extant signs of platform reduction.

The tool assemblage (Table 5) is largely on flint (98\%), and frequently on blades (41.3\%). A wide range of tools is present; microliths constitute the dominant tool class (30\%), with scalenes making up $50 \%$ of the identifiable forms (Table 6). Many of these have retouch on the lateral edge opposite 
Table 3: Chipped stone assemblage recovered from Criet Dubh features, 2014

\begin{tabular}{lllllll}
\hline Material & Flint & $\begin{array}{l}\text { Pitch- } \\
\text { stone }\end{array}$ & Quartz & $\begin{array}{l}\text { Rock } \\
\text { Crystal }\end{array}$ & TOTAL & \% \\
\hline Flakes & 853 & 0 & 13 & 3 & 869 & 31.1 \\
Blades & 95 & 0 & 0 & 0 & 95 & 3.4 \\
Irregular blades & 18 & 0 & 0 & 0 & 18 & 0.6 \\
Spalls & 9 & 0 & 0 & 0 & 9 & 0.3 \\
Microburins & 10 & 0 & 0 & 0 & 10 & 0.4 \\
CTEs & 16 & 0 & 0 & 0 & 16 & 0.6 \\
Cores & 19 & 1 & 0 & 0 & 20 & 0.7 \\
Indeterminate & 1382 & 0 & 64 & 3 & 1449 & 51.8 \\
$<3$ mm & 202 & 0 & 8 & 0 & 210 & 7.5 \\
\hline Total & $\mathbf{2 6 0 4}$ & $\mathbf{1}$ & $\mathbf{8 5}$ & $\mathbf{6}$ & $\mathbf{2 7 9 6}$ & $\mathbf{1 0 0 . 0 \%}$ \\
\hline
\end{tabular}

Table 4: Cores, Criet Dubh 2014

\begin{tabular}{llllllll}
\hline & $\begin{array}{l}\text { Sub- } \\
\text { pyramidal }\end{array}$ & $\begin{array}{l}\text { Irreg/ } \\
\text { amor. }\end{array}$ & Flat & Flake & Pebble & Fragment & Total \\
\hline Platform & 2 & 5 & 1 & 1 & 0 & 2 & 11 \\
Plat/ bipolar & 1 & 1 & 0 & 0 & 1 & 0 & 3 \\
Bipolar & 0 & 2 & 3 & 0 & 0 & 0 & 5 \\
Indeterminate & 0 & 0 & 0 & 0 & 0 & 1 & 1 \\
\hline Total & $\mathbf{3}$ & $\mathbf{8}$ & $\mathbf{4}$ & $\mathbf{1}$ & $\mathbf{1}$ & $\mathbf{3}$ & $\mathbf{2 0}$ \\
\hline
\end{tabular}

Table 5: Tool assemblage, Criet Dubh 2014

\begin{tabular}{llllll}
\hline & Flint & Quartz & $\begin{array}{l}\text { Rock } \\
\text { Crystal }\end{array}$ & TOTAL & \% \\
\hline Awl & 2 & 0 & 0 & 2 & 1.3 \\
Backed & 1 & 0 & 0 & 1 & 0.7 \\
Burin & 3 & 0 & 1 & 4 & 2.6 \\
Denticulate & 2 & 0 & 0 & 2 & 1.3 \\
Fragment & 11 & 0 & 0 & 11 & 7.2 \\
Marginally retouched & 23 & 0 & 0 & 23 & 15.0 \\
Microlith & 45 & 1 & 0 & 46 & 30.1 \\
Notch & 24 & 0 & 0 & 24 & 15.7 \\
Other & 1 & 0 & 0 & 1 & 0.7 \\
Pièce esquillée & 3 & 1 & 0 & 4 & 2.6 \\
Scraper & 7 & 0 & 0 & 7 & 4.6 \\
Truncation & 5 & 0 & 0 & 5 & 3.3 \\
Used & 23 & 0 & 0 & 23 & 15.0 \\
\hline Total & $\mathbf{1 5 0}$ & $\mathbf{2}$ & $\mathbf{1}$ & $\mathbf{1 5 3}$ & $\mathbf{1 0 0 . 0 \%}$ \\
\hline
\end{tabular}

Table 6: Microliths, Criet Dubh 2014

\begin{tabular}{lll}
\hline Type & No. & $\begin{array}{l}\text { \% of } \\
\text { identifiable }\end{array}$ \\
\hline Scalenes & 12 & 50.0 \\
Straight backed blades & 6 & 25.0 \\
Crescents & 3 & 12.5 \\
Obliquely blunted blades & 2 & 8.3 \\
Irregular & 1 & 4.2 \\
Fragments & 21 & 0 \\
\hline Total & $\mathbf{4 5}$ & $\mathbf{1 0 0 \%}$ \\
\hline
\end{tabular}


to the backing, and a number of them have a tang-like end, often on the proximal end. There are small numbers of other tools present, made on flakes - truncations, awls, denticulates, backed flakes, pièces esquillées and burins (often showing edge damage).

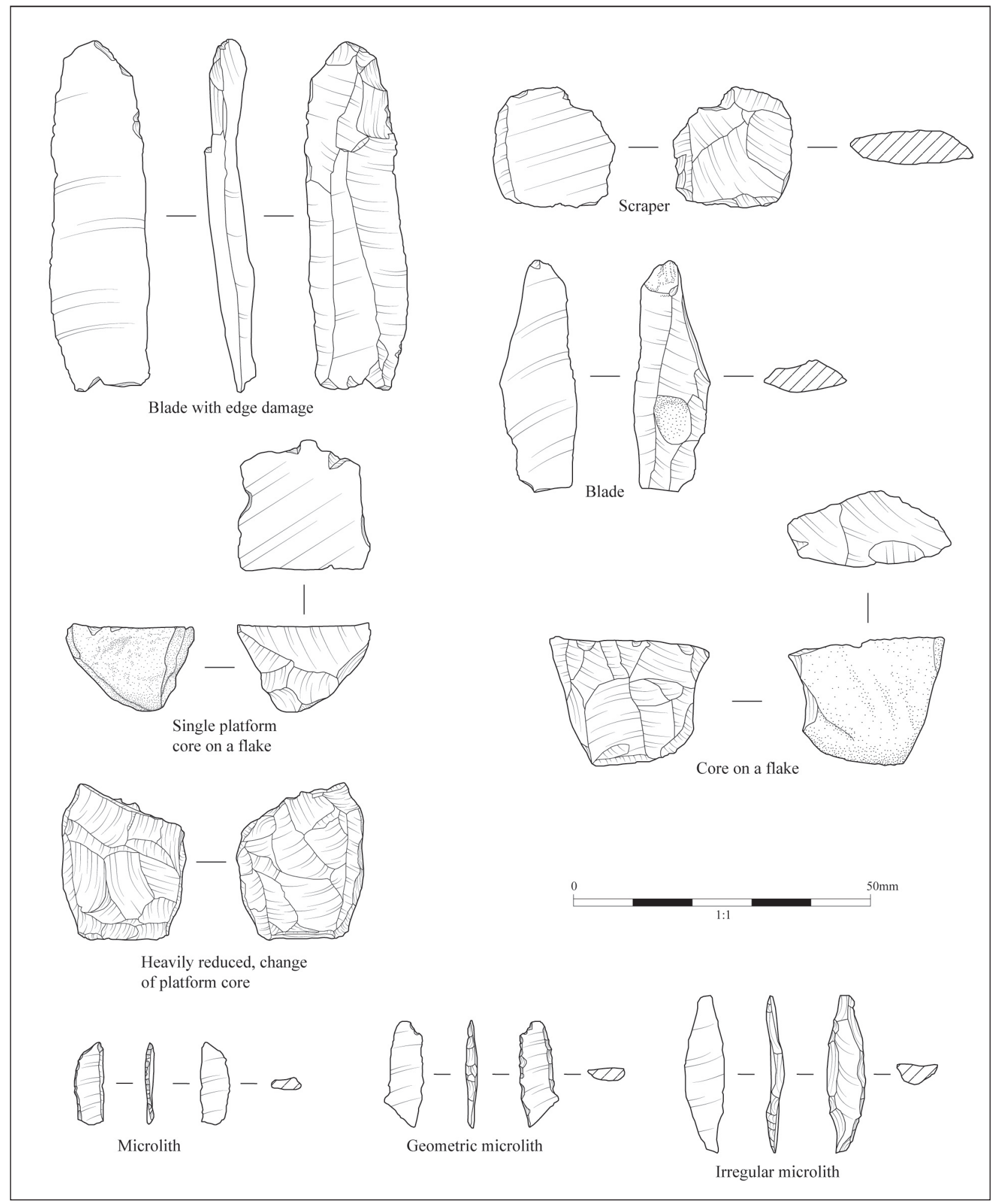

Figure 9: Sample of the chipped stone artefacts from Criet Dubh 
Of the 83 features recorded at the site, 15 yielded chipped stone artefacts mostly concentrated in the capping spreads (F1 and F70), the northern part of the sequence of stone-lined fire pits (the fill of Feature 55) and the fill of the intercutting pits/hearth (Features 6-8) to the south of the site. Table 7 provides a summary of the main measures of variability between these assemblages.

In summary, the chipped stone assemblage from Criet Dubh falls into the Narrow Blade tradition, with close similarity to Mesolithic assemblages within the region. Two aspects of the assemblage are especially notable. Firstly, there is little sign of knapping activities at Criet Dubh, with low levels of small fraction, and few cores. Those present are small and heavily worked. Only one shows extant bladelet removals, but many could have been used for bladelet removal in earlier stages of their reduction. The small and irregular nature of both platform and bipolar cores suggest they were being used in their final stages at Criet Dubh. It is interesting that platform reduction remains dominant, even in the final, heavily used stages of these cores. A pitchstone core is also likely to have been heavily curated, as seen in its small size and irregular form.

Secondly, the Criet Dubh assemblage is made up of a series of sub-assemblage types: quartz dominated rather than flint; flake dominated rather than blade; no microliths; very few tools of any sort. No chronological patterning is evident and we suspect that the principle determinant is variation in activities across the site from which waste was deposited into features, either by primary discard, such as into the edge of fire-pits, by secondary discard, such as being swept into rubbish pits, or by post-depositional erosion.

\section{Dating and chronology}

Twenty-six samples of charred plant remains were submitted to the SUERC and Beta Analytic radiocarbon laboratories for AMS dating (Table 8). Twenty-two of these were single-entity fragments of charred hazelnut shell collected in sieve residues extracted from the black organic-rich deposits containing artefacts found in-filling the multiplex of Mesolithic features. A further four samples were obtained from single fragments of burnt Corylus (SUERC-58136 and SUERC-58144) and wood charcoal (SUERC-58649, indeterminate; Beta-288420, twig wood).

To provide a chronological framework for the start and end of Mesolithic activity at Criet Dubh we constructed a Bayesian site model (Figure 10) using OxCal v. 4.2 radiocarbon plotting software (Bronk Ramsey 2009); this using the IntCal13 atmospheric curve for calibration (Reimer et al. 2013). We acknowledge that modelled outputs are built on our current chrono-stratigraphic interpretation of the features recorded - these being subject to revision in light of new priors being added to existing Bayesian chronological frameworks. Following standard protocol for the reporting of modelled radiocarbon dates, posterior density estimates are indicated by italicized text and are given as 95\% probability ranges (Figure 10; Table 8). Using the Sum command in OxCal, we extracted a summed calibrated probability distribution from the Bayesian chronological site model 


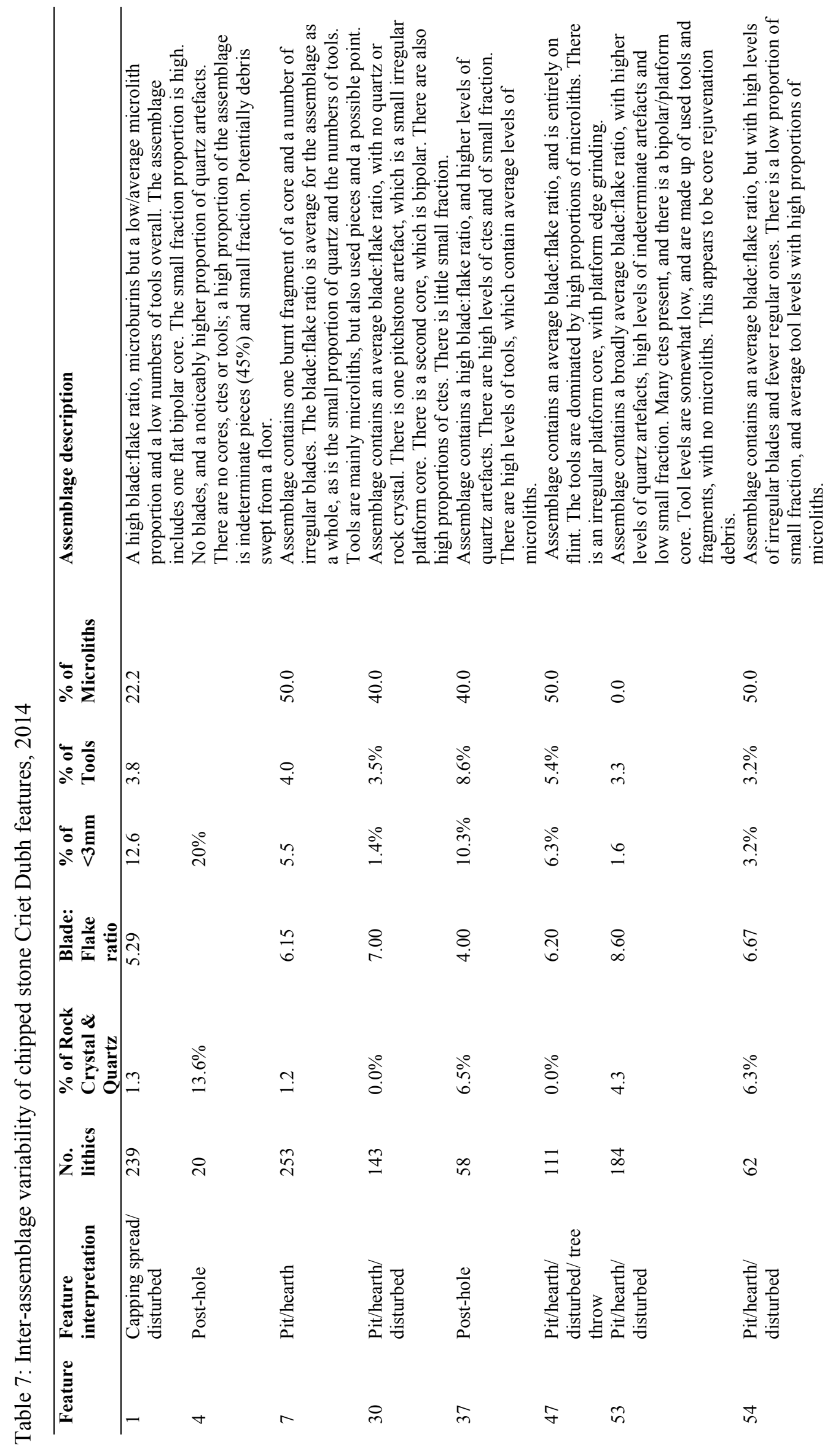




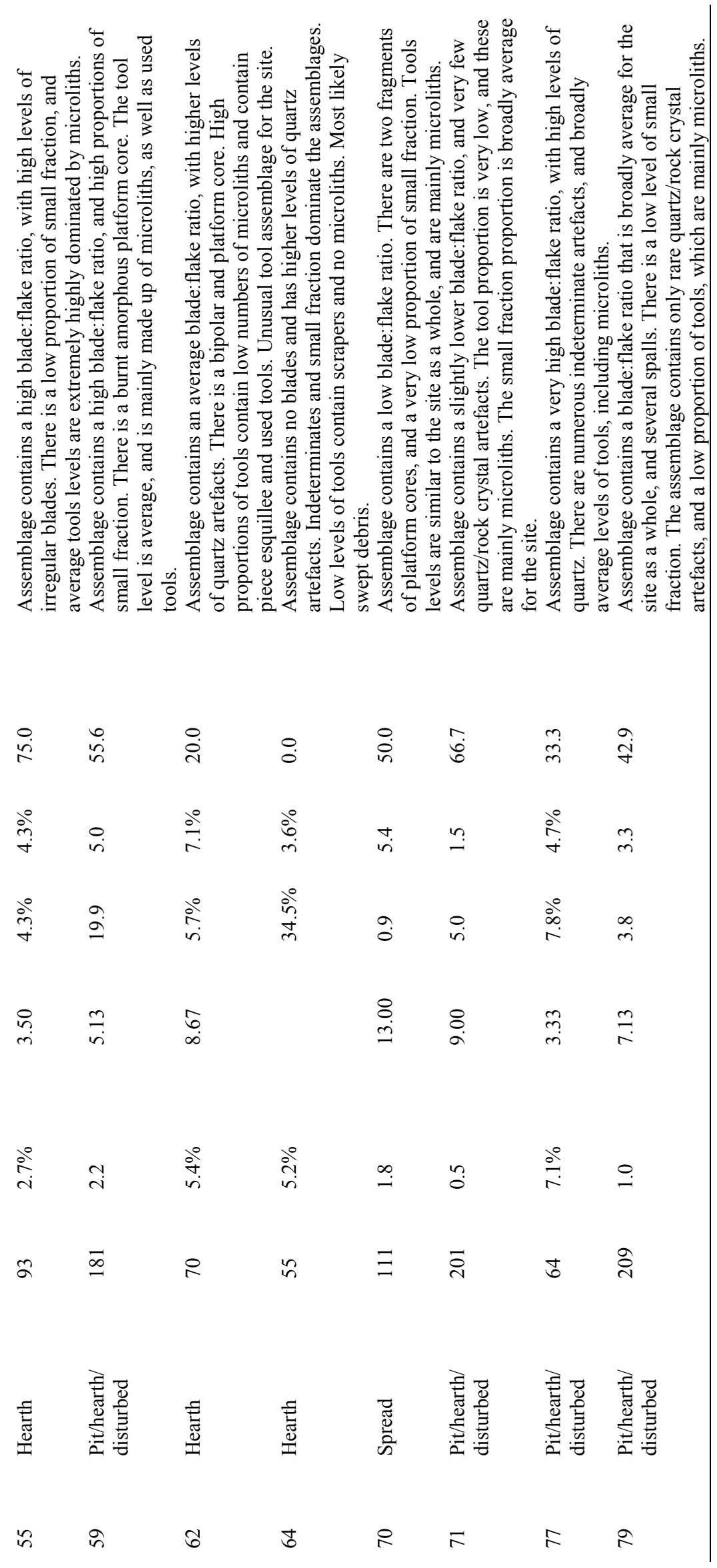


to provide a prima facie indication for the degree of continuity in Mesolithic occupation at the site (Figure 10).

The validity of the model can be measured by its agreement index value ([Amodel]), which in this study falls above the acceptable threshold of $>60 \%$ with convergences [C] in excess of $95 \%$ (Bronk Ramsey 2011). The range of radiocarbon determinations indicated two main phases of Mesolithic occupation. The first falls between c. 8320 and 8230 cal BC (Table 8) and relates to just two of the 26 dates, these coming from two adjacent features (Feature 4 and 83) from which no artefacts were recovered. The second phase of Mesolithic activity at Criet Dubh is centred on the multi-phase sequence of stone-lined fire pits located within the interior of the purported hut dating to c. 7100 to 6580 cal BC (Table 8)

Difference and Span commands were used to extract information concerning the period of time between phases of occupation and their duration. These suggested 1,454-1,380 years of separation (at 95\%.4 confidence) and a duration of 80-340 years for the second phase of activity (at 95.4\% confidence) (Figure 11).

Table 8: Radiocarbon dates and Posterior Density Estimates for Mesolithic activity at Criet Dubh, Isle of Mull.

\begin{tabular}{|c|c|c|c|c|c|c|}
\hline${ }^{14} \mathrm{C}$ & & & & & & $\begin{array}{c}\text { Posterior } \\
\text { density } \\
\text { estimate } \\
\text { (cal BC) }\end{array}$ \\
\hline $\begin{array}{l}\text { no. } \\
\text { (R) }\end{array}$ & Lab. code & Material & Context & $\begin{array}{l}\delta^{13} \mathrm{C} \\
(\%)\end{array}$ & $\begin{array}{c}{ }^{14} \mathrm{C} \text { date } \\
\text { (yr BP) }\end{array}$ & $\begin{array}{c}{[95.4 \%} \\
\text { probability] }\end{array}$ \\
\hline 1 & SUERC-58649 & Wood charcoal (indet.) & Feature 38 & -26.2 & $7732 \pm 28$ & $6650-6540$ \\
\hline 2 & SUERC-58158 & Charred hazelnut shell & Feature 62 & -25.4 & $7741 \pm 29$ & $6650-6490$ \\
\hline 3 & SUERC-58135 & Charred hazelnut shell & Feature 1 & -23.5 & $7795 \pm 29$ & $6690-6590$ \\
\hline 4 & SUERC-58165 & Charred hazelnut shell & Feature 64 & -25.0 & $7795 \pm 30$ & $6660-6580$ \\
\hline 5 & SUERC-58164 & Charred hazelnut shell & Feature 64 & -25.7 & $7797 \pm 29$ & $6660-6580$ \\
\hline 6 & SUERC-58648 & Charred hazelnut shell & Feature 7 & -23.4 & $7811 \pm 28$ & $6690-6590$ \\
\hline 7 & SUERC-58138 & Charred hazelnut shell & Feature 6 & -26.0 & $7824 \pm 29$ & $6740-6590$ \\
\hline 8 & Beta-221402 & Charred hazelnut shell & Feature 55 & -26.4 & $7830 \pm 80$ & $6740-6610$ \\
\hline 9 & SUERC-58163 & Charred hazelnut shell & Feature 63 & -27.5 & $7830 \pm 30$ & $6810-6650$ \\
\hline 10 & SUERC-58156 & Charred hazelnut shell & Feature 55 & -26.2 & $7844 \pm 29$ & $6730-6620$ \\
\hline 11 & SUERC-58159 & Charred hazelnut shell & Feature 63 & -25.3 & $7852 \pm 29$ & $6820-6660$ \\
\hline 12 & SUERC-58147 & Charred hazelnut shell & Feature 46 & -25.6 & $7852 \pm 30$ & $6780-6600$ \\
\hline 13 & SUERC-58134 & Charred hazelnut shell & Feature 1 & -26.6 & $7858 \pm 29$ & $6810-6630$ \\
\hline 14 & SUERC-58145 & Charred hazelnut shell & Feature 30 & -27.5 & $7879 \pm 29$ & $6900-6640$ \\
\hline 15 & SUERC-58146 & Charred hazelnut shell & Feature 38 & -26.6 & $7894 \pm 29$ & $7010-6640$ \\
\hline 16 & SUERC-58155 & Charred hazelnut shell & Feature 55 & -25.3 & $7900 \pm 29$ & $6740-6640$ \\
\hline 17 & Beta- 288420 & Twig charcoal (indet.) & Feature 1 & -25.5 & $7900 \pm 40$ & $7030-6640$ \\
\hline 18 & SUERC-58154 & Charred hazelnut shell & Feature 52 & -25.0 & $7910 \pm 29$ & $7040-6710$ \\
\hline 19 & SUERC-58139 & Charred hazelnut shell & Feature 8 & -27.3 & $7941 \pm 29$ & $7030-6690$ \\
\hline 20 & SUERC-58136 & Wood charcoal (Corylus) & Feature 2 & -26.5 & $7951 \pm 30$ & $7040-6700$ \\
\hline 21 & SUERC-58149 & Charred hazelnut shell & Feature 50 & -27.1 & $7960 \pm 30$ & $6980-6690$ \\
\hline 22 & SUERC-58157 & Charred hazelnut shell & Feature 62 & -29.0 & $7988 \pm 30$ & $7050-6770$ \\
\hline 23 & SUERC-58144 & Wood charcoal (Corylus) & Feature 29 & -27.2 & $8062 \pm 30$ & $7090-6830$ \\
\hline 24 & SUERC-58153 & Charred hazelnut shell & Feature 52 & -27.0 & $8133 \pm 29$ & $7140-7040$ \\
\hline 25 & SUERC-58137 & Charred hazelnut shell & Feature 4 & -27.7 & $9070 \pm 29$ & $8310-8240$ \\
\hline 26 & Beta-288421 & Charred hazelnut shell & Feature 83 & -29.3 & $9080 \pm 40$ & $8320-8240$ \\
\hline
\end{tabular}




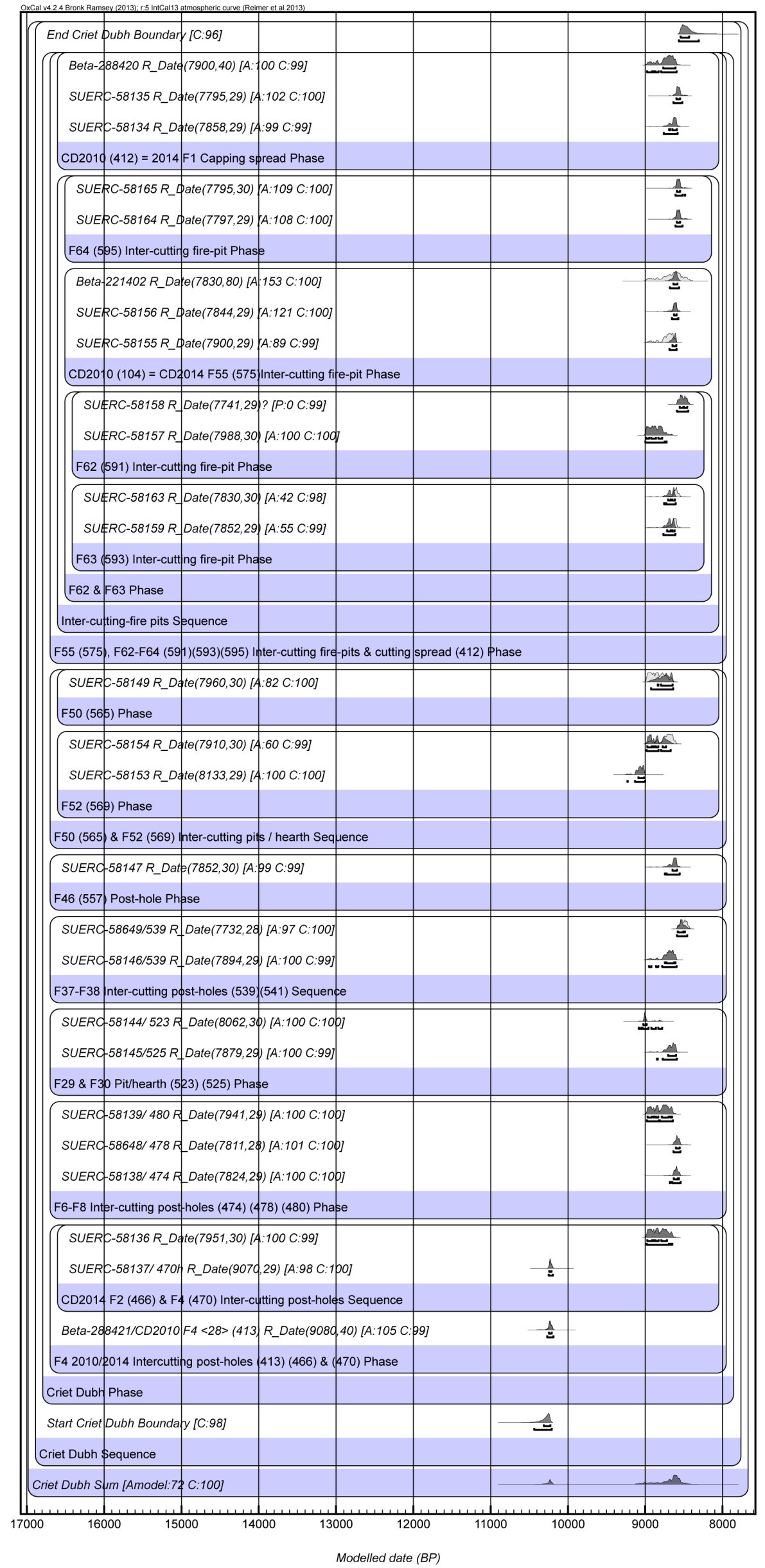

Figure 10: Bayesian chronological plot showing posterior density estimates for Mesolithic activity at Criet Dubh, with a summed probability distribution at the base of the plot indicating two separate phases of occupation 

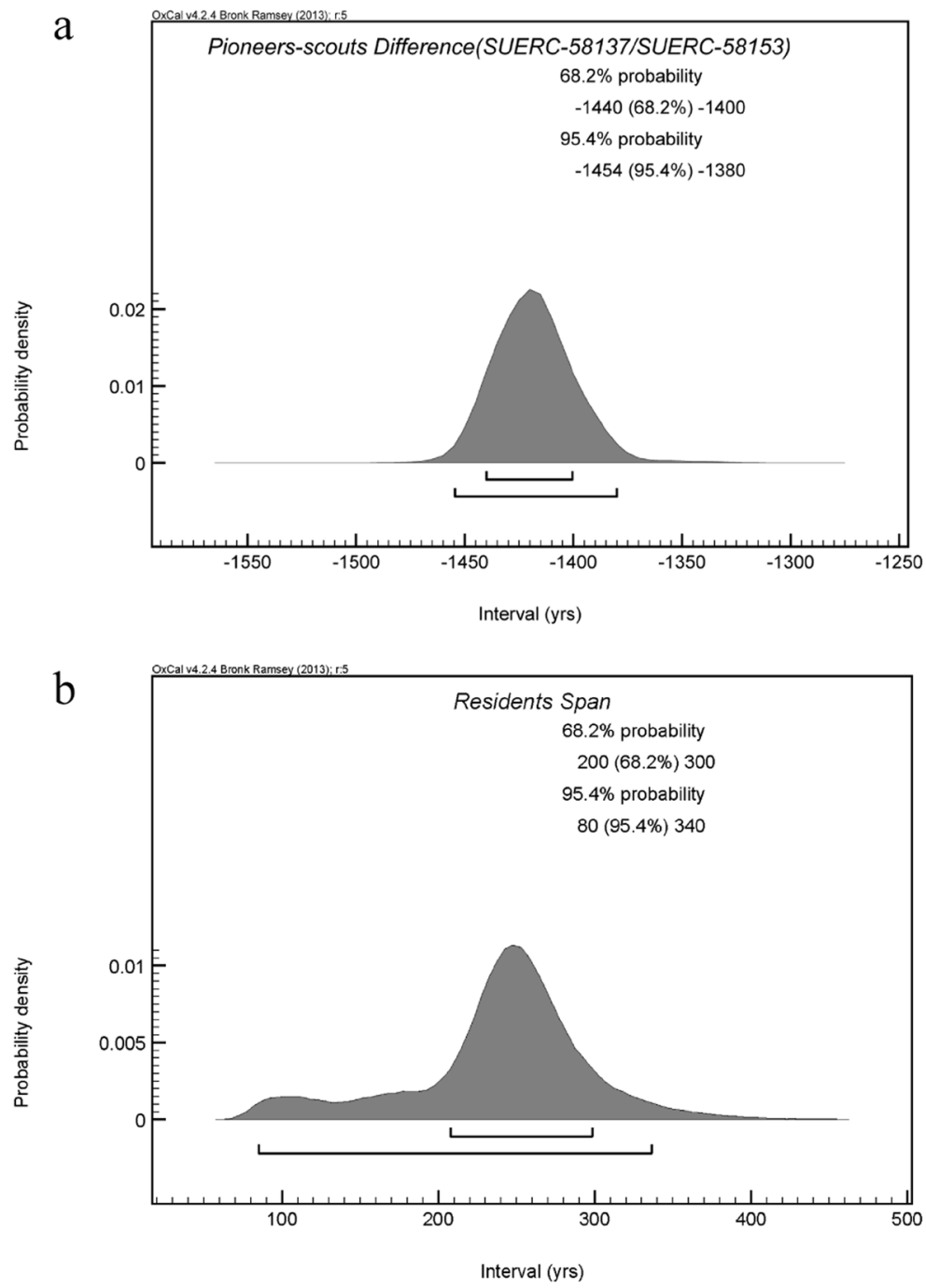

Figure 11: (a) OxCal plot showing the likely separation in time between the two phases of occupation at Criet Dubh; (b) Oxcal plot showing the likely span of the second phase of occupation at Criet Dubh.

A shelter, a pit-house, or something else?

Does Criet Dubh fit into the 'shelter' or 'pit-house' categories, or neither? Figure 12 draws on the interpretations of features as stake holes, post-holes and fire-pits proposed in Table 2. We recognize that these interpretations are problematic, because of the issues noted above: contemporaneity, preservation and equifinality; we also note that the low rocky crags between which the features are located might reasonably be considered as part of the structure. Nevertheless, the number and distribution of features has similarities to those from Mount Sandel, Howick and East Barns, and indicate a more substantial structure - or structures - than the shelters in Table 1, with the possible exception of Broom Hill. Notable similarities to pit-houses include: the circular arrangement of features; the overall dimension of that arrangement (approximately $6 \mathrm{~m}$ ); the mix of post-holes and stake-holes; the absence of a central post-hole (which is otherwise only known at Howick Phase 3 structure); and the location of hearths within the arrangement. 


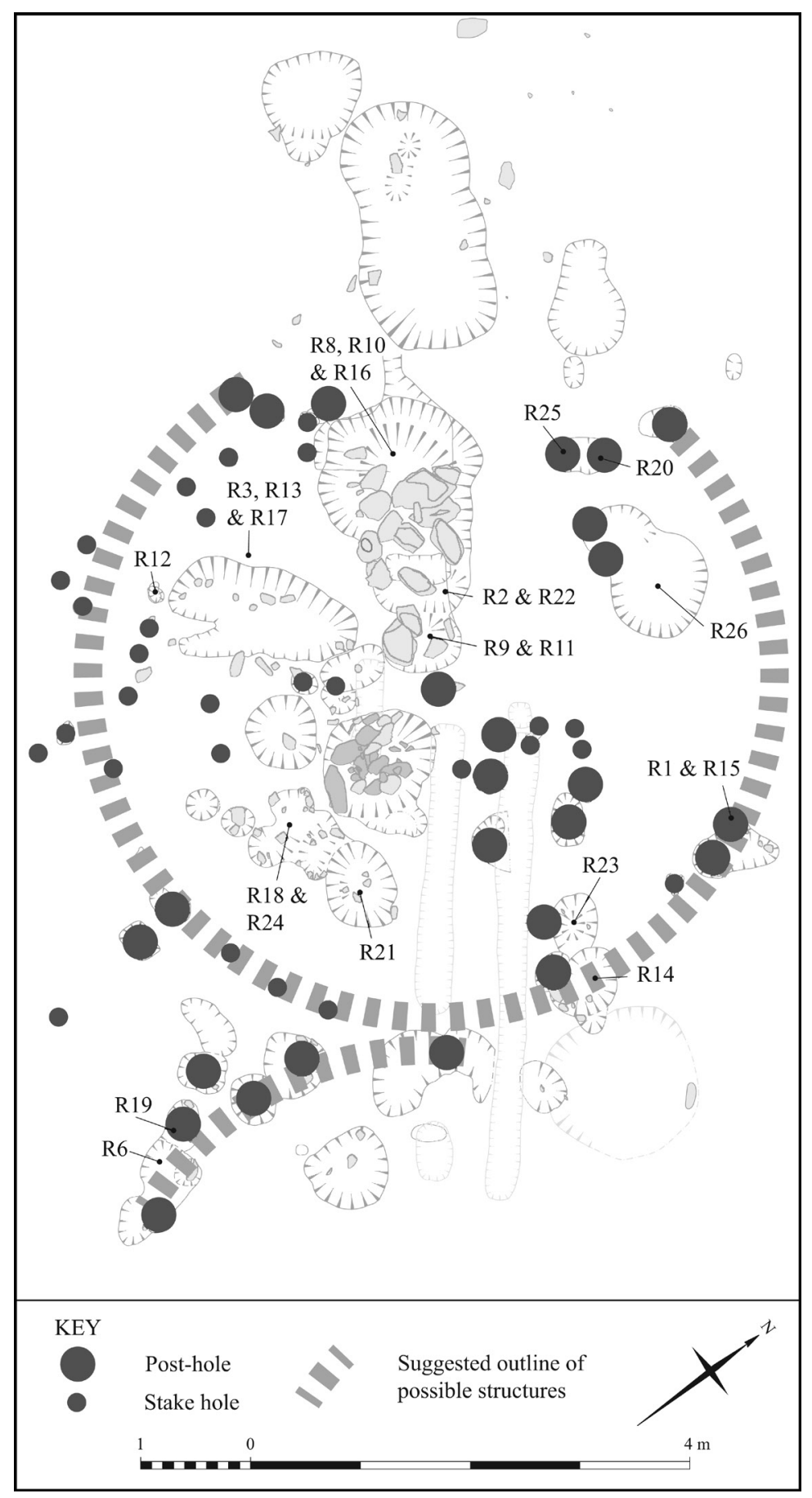

Figure 12: Schematic distribution of the stake-holes, post-holes and fire-pits at Criet Dubh, indicating where samples were taken from radiocarbon dating and interpreted as remains of a hut

Conversely, Criet Dubh appears to lack some key features of the pit-houses. It seems unlikely that truncation of the deposits can account for the absence of a sunken floor and of post-holes for timbers of an equivalent size to those inferred at Mount Sandel, Howick, East Barns and Echline Fields - although the shelter provided by the adjacent rocky outcrops might have made such timbers unnecessary. Pebbles tools are notably absent at Criet Dubh while prominent at Howick and East Barnes. With regard to dating, the initial phase of activity fits with that of the pit-houses (8300-7600 cal BC), but this is only represented by two dates coming from adjacent features at Criet Dubh, and 
has no directly associated chipped stone artefacts. The majority of dates relate to a second phase of activity, c. 7100 to $6560 \mathrm{cal} \mathrm{BC}$, during which the structure is likely to have been (re?)-constructed and in use.

In summary, Criet Dubh does not comfortably fit into either the shelter or the pit-house categories of Mesolithic structures. The most reasonable interpretation is that the features represent a hut with an entrance at the northeast, hearths just within the interior, and internal features, possibly racks. As such, in terms of its size and construction, Criet Dubh, appears to sit between shelters and pithouses, as is the case for Broom Hill. This serves to emphasize the continuous range of variability in Mesolithic structures in Britain, as seen within and between the shelter and pit-house categories, while leaving the pit-houses as a distinct and chronologically limited category of structure. We suspect that the absence of coarse stone artefacts at Criet Dubh, the limited evidence for flint knapping, and its already sheltered location between two linear outcrops of rock, suggest the structure was used for a specialized economic activity, perhaps smoking fish and meat, rather than or in addition to - its use for domestic activities.

\section{OCCUPATION SPANS OR ACTIVITY EVENTS?}

\section{Interpretations based on occupation spans}

The interpretation of pit-houses has been influenced by the perceived labour and time costs of their construction, as explored through experimental archaeology (Waddington 2007). Interpretation has also drawn on the use of multiple radiocarbon determinations and the techniques of Bayesian analysis. On the basis of a Bayesian analysis of the 33 radiocarbon dates from Howick, Waddington et al. (2007, 196-98) argued that a hut stood at the site for 100-300 years, describing it as a "a permanent structure" and discussed various scenarios for its use, ranging from seasonal to fully sedentary occupation, concluding that it was a structure "that was used for much of each year". Gooder $(2007,57)$ similarly interpreted the "robust and time-consuming construction" at East Barns as representing a "planned, long duration of occupation", that was described as "near permanent" and an "economic strategy of sedentism". Bayliss and Woodman $(2009,118)$ reached similar conclusions from Mount Sandel, suggesting its use persisted over 80-290 years, representing “one or two generations", while Robertson et al. $(2013,57)$ proposed that Echline and the other pithouses indicates "a degree of sedentism or extended residence not traditionally identified with sites of this period" (i.e. the Mesolithic).

These are all reasonable interpretations when based on the occupation spans as derived from Bayesian analysis, the construction costs of the pit-houses as inferred from the features present, and/ or the presence of intercutting features suggesting multiple occupations. The evidence from Criet Dubh could provide a similar interpretation: the Phase 2 occupation has a span of 80-340 years 
(Figure 11) during which there appears to have been a substantial structure with repeated re-cutting of interior fire-pits.

While reasonable, we are cautious about such interpretations invoking partial or full sedentism. When such behavior is attested in the archaeological record, such as for the Early Natufian of SW Asia, the Ertebølle of Southern Scandinavia, the Jomon of Japan and the NW coast of America, there is a considerable elaboration of material culture, sites with multiple dwellings and the creation of cemeteries (see Mithen 2003 for a review). Such evidence is unknown in the 'pit-house' phase (8300-7600 cal BC) of the British Mesolithic. As such, we suggest an alternative method for the analysis of radiocarbon dates from the pit-houses and Criet Dubh, which leads to interpretations that stress mobility within a sparsely populated landscape.

\section{Interpretations based on activity events}

We will consider the radiocarbon evidence from the view of activity events (Wicks \& Mithen 2014) rather than span analysis. An activity event analysis simply provides a measure of the degree of statistical consistency amongst radiocarbon determinations, the premise being that a tally of groups of statistically consistent dates plus individual statistically inconsistent dates provides a proxy for the minimum number of events at the site that would be necessary to account for the radiocarbon record. The term 'event' is of course problematic because statistically consistent radiocarbon dates might still allow for a number of successive events occurring at any point in time bracketed within a calibrated date range, distributed either uniformly or randomly.

Acknowledging this caveat, assessing the number of activity events is the radiocarbon equivalent to assessing the MNI required to account for an assemblage of animal bones at an archaeological site. Just as it is prudent to refer to the minimum number of individuals when cataloging a faunal assemblage, it is equally prudent to refer to the minimum number of events (MNE) required to create the assemblage of radiocarbon dates - an event being either a single moment in time or a succession of moments that cannot be distinguished between by the radiocarbon dating evidence. It could be argued that Bayesian span analysis does the opposite: it provides the maximum duration of time that the radiocarbon dates might represent, which seems equivalent to citing the maximum number of individuals that might have contributed to a faunal assemblage. The Bayesian span analysis appears inherently more suited to sites when the default assumption is of continuous occupation, such as a farming or urban settlement; when dealing with hunter-gatherers the default should be a pattern of intermittent occupation, whether seasonal, of an inter-annual, or a sporadic basis. That does not preclude the possibility of identifying sedentary behavior, just as we might identify highly mobile behavior in the later prehistoric and historic periods.

As with the MNI of a faunal assemblage, there might be a variety of reasons why an MNE underestimates the true number of activity events at an archaeological site: plateaus in the calibration curve might bias the distribution of dates; disparities between the actual duration of activity and 
the age of related dated material; the destruction of evidence of earlier events by later activity; excavation sampling strategies; human activities that fail to leave any archaeological traces containing material that can be radiocarbon dated.

We used the Combine command in OxCal to determine statistical consistency. This indicated that the existing chronological evidence at Criet Dubh could be accounted for by six activity events. Five groups of dates were statistically consistent with some dates being members of two groups, whilst a single date (SUERC-58153) was entirely statistically inconsistent (MNE=6; Table 9; Figure 13). Noting that an 'event' might be a series of successive visits that cannot be chronologically distinguished, we used the combined calibrated date ranges to provide an indication of the span of years that an event could have occurred within (at 95.4\% confidence levels). The earliest activity event indicated a single occupation or a series of visits in close succession falling at any point within a 50 year period centered on 8280 cal BC (Phase 1). Subsequent activity events occurred across a 100 year span centred on 7080 cal BC, a 240 year span centred on 6970 cal BC, a 130 year span centred on $6750 \mathrm{cal} \mathrm{BC}$, a 30 year span centred on $6650 \mathrm{cal} \mathrm{BC}$ and a 50 year span centred on 6630 cal BC (all within Phase 2). Hence the span of 80-340 years for Phase 2 as derived from Bayesian analysis (Figure 11), might be accounted for by no more than five separate visits to the site, with events two and three possibly separated in time by as much as 280 years, events three and four by 405 years and events four and five by 180 years. The uppermost events fall in closer succession separated in time by up to 60 years (Figure 13).

For Howick, Waddington \& Wicks (2017, Table 1) calculated an MNE of 3. Using the Combine command in Oxcal, the 33 radiocarbon dates, that provided an occupation span of 100-300 years, fall into no more than three statistically consistent groups indicating the occurrence of activity events within a 50 year span centred on $7770 \mathrm{cal} \mathrm{BC}$, a 100 year span centred on $7600 \mathrm{cal} \mathrm{BC}$ and a 140 year span centred on 7410 cal BC (Table 10; Figure 13). Separations in time by up to 245 years between events one and two and 310 years between events two and three conflict with the field observations of no evident hiatus in any of the archaeological deposits that could denote episodes of prolonged abandonment (Waddington 2007, 196). We note the word 'evident' and the difficulty of inferring periods of abandonment within re-used structures. A scenario of intermittent occupation at Howick matches Waddington et al's $(2007,198)$ caution that a permanent structure does not necessarily imply permanent and continuous residency. As illustrated in Figure 13, the entire span of activity at Howick might be represented by no more than 3 events; alternatively there might have been 33 separate visits to the site, each represented by one of the radiocarbon dates, with these being clustered into three periods of activity separated by periods of abandonment.

Using the same OxCal Combine method, the radiocarbon dates from Echline also have an MNE of 3, with events widely separated in time by as much as 1195 years after the first event centered on 8290 cal BC and 360 years after the second event centred on 7250 cal BC (Table 10; Figure 13). Only the first of these events relates to activity within the hut structure itself - the later events 


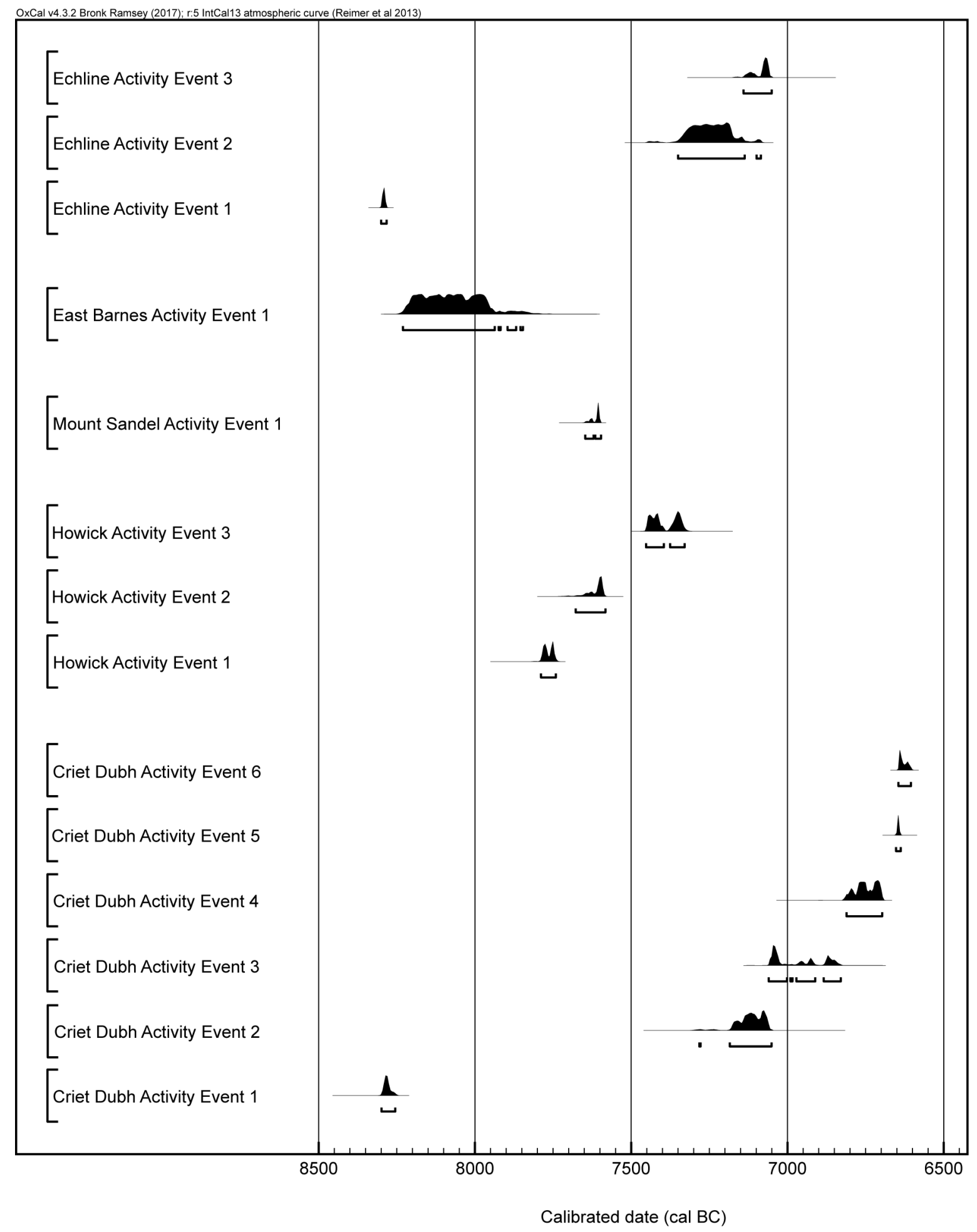

Figure 13: Activity events at Criet Dubh and pit-houses in Mesolithic Britain arising from deposits that sealed the post-holes (Robertson et al. 2013). Even more striking, the 27 radiocarbon single-entity dates drawn upon by Bayliss \& Woodman (2009) in their re-analysis of the Mount Sandel hut(s)/pit-house(s) are all statistically consistent with each other giving an MNE of 1: there might have been one single event at Mount Sandel that fell within a 60 year span centered on 7610 cal BC, located within the Bayesian derived occupation span of 80-290 years 
(Table 10; Figure 13); alternatively there might have been as many as 27 separate events (each represented by a single radiocarbon date) falling within this 60 year period. As such, the sequence of huts/pit-houses at Mount Sandel might have been built in quick succession within a time period contained within that single activity event (60 years). The three radiocarbon dates from East Barns are also statistically consistent with each other $(\mathrm{MNE}=1)$, indicating the possibility of a single event centred on 8080 cal BC (Table 10; Figure 13).

Broom Hill is also interesting in this regard, although the radiocarbon dates are less helpful by having relatively large standard deviations. Nevertheless, the three dates from the base of the occupation hollow indicate one activity event at c. $6510 \mathrm{BC}$. The two later dates from higher in the archaeological sequence represent independent events occurring c. $5800 \mathrm{BC}$ and $5270 \mathrm{BC}$ separated in time by up to a 550 year interval, with the uppermost archaeological deposits showing a period of abandonment.

Even when one recognizes that a single activity event might represent a close succession of events and bears in mind how, as with MNI for a faunal assemblage, the MNE of a site might be an underestimate, the small number of activity events for the pit-houses and their potentially wide spacing apart in time appears incongruous with interpretations of these structures being continuously used over several generations with economic strategies of partial or full sedentism. This is most notable for Howick with its large number of radiocarbon dates, suggesting that the low number of activity events is unlikely to be a consequence of sample bias from the archaeological record.

\section{FURTHER ARCHAEOLOGICAL, ETHNOGRAPHIC AND ARCHAEOLOGICAL PERSPECTIVES}

\section{Were pit-houses for winter occupation?}

The low number of activity events at the pit-houses is even more striking when one considers that several Mesolithic sites lacking any evidence of structures and having fewer radiocarbon dates, have higher numbers of activity events: Rubha Port an t-Seilich (Isle of Islay) has only 9 dates but 6 events (Mithen et al. 2015) and Fiskary Bay (Isle of Coll) has only 6 dates but three activity events (Wicks \& Mithen 2017).

Both Rubha Port an t-Seilich and Fiskary are in attractive coastal locations for fishing and foraging, and with good harbours for small boats. Hence, such repeated visits are not surprising. Neither location appears to have required 'investment in place' as represented by the construction of a hut - although neither site has received sufficient open area excavation to absolutely discount this possibility. The estuarine and coastal settings of Mount Sandel, East Barns, Howick and Echline are unlikely to have been significantly different from those at Rubha Port an t-Seilich and Fiskary, 
and hence it is unclear why such structures were constructed and then appear to have been used so infrequently.

One possible reasons for constructing pit-dwellings at some locations but not at others relates to seasonality. Fretheim et al. (2016) note that pit-houses known from the ethnographic record are consistently associated with three conditions: (1) a non-tropical climate; (2) a seasonal settlement pattern with pit-house occupation in the cold season; (3) a reliance on stored food while the pit house is inhabited. As such, the pit-houses from the British Mesolithic might relate to winter occupation in locations where stored food could be accumulated, while occupation at sites with multiple activity events but without structures, such as at Fiskary and Rubha Port an t-Seilich, might have been predominately in the spring and summer months. The archaeological evidence is not supportive of this proposition: neither Mount Sandel nor Howick provide compelling evidence for winter occupation alone (Woodman 1985; Waddington 2007), although the problem of secondary reuse and the mixing of occupation deposits remain. Moreover, large quantities of charred hazelnut shells at Fiskary Bay and Rubha Port an t-Seilich suggest autumn/winter occupation.

\section{Were the pit-houses re-occupied after lengthy periods of abandonment?}

A further ethnographic observation by Fretheim et al. (2016) is that pit-houses are often re-used, with people having been attracted to where others had once lived. They note how this effect can be seen along the Beagle Channel in South America today as modern campers often take advantage of archaeological features, lighting their fires or pitching their tents within the remnants of past huntergatherer structures. That is no more than the continuation of the traditional occupation pattern of hunter-gatherers from the region, encompassing various groups known as the Ona (also known an Selk'nam), the Yahgan (also known as the Yaghanes, Yámanas), the Alacalufes and the Chonos.

Lothrop $(1928,179)$ described how the Yahgan's conical wigwams were substantial structures: up to ten feet high, built from branches and thatched with leaves; they were 10-15 feet in diameter with sunken floors on average two feet deep and with internal bunks made from logs secured with stakes. These wigwams, perhaps better described as conical log dwellings (Vidal 1999), were only occupied intermittently - rarely did these and other hunter-gatherers from the region pass a few weeks or even a few days at a given spot (Lothrop 1928; Orqueral et al. 2011). The structures were not dismantled but left for use on a future occasion, these being located at a preferential foraging locations. Re-occupation involved minor repairs, making use of the former poles and presumably with a new thatch when required (Vidal 1999; Orqueral et al. 2011). Had a death occurred within a Yahgan wigwam, it might remain unoccupied for many decades until the memory of the deceased had passed (Lothrop 1028).

From this perspective, and in light of the activity event analysis, one might imagine dilapidated structures at, say, Criet Dubh, Howick and East Barns, being re-built and re-occupied after an extended period of abandonment within a sparsely populated landscape. They were returned to 
because they had been originally built at a particularly advantageous foraging location, notably next to both estuaries and terrestrial woodland.

The re-use of past structures might involve the gradual development of what has the appearance of a substantial pit-house on excavation, despite never having received a single event of large-scale labour investment.. The intermittently occupied Yaghan dwellings illustrate how sunken floors might be inadvertently enhanced: wild current bushes and other shrubs would take root in the midden deposits that accumulated around the wigwams, followed by a tall, broad-leafed perennial grass forming a surrounding screen and exaggerating the extent of the hollow floor (Bridges (1948, 73).

Might the sunken floors at Howick, East Barns and Echline have been created by gradual attrition of the ground surface or soil development on the exterior rather than by intentional design? O'Malley \& Jacobi (1978) suggested that the hollow at Broom Hill might have been caused by erosion. In summary, Fretheim et al. $(2016,188)$ provide a warning that we need to heed: "dwellings that appear to be pit-houses should not automatically be given the status of permanent dwellings, for long term or repeated occupations".

Ingold's (2000) 'dwelling perspective' is of relevance here. He suggests that houses should be considered as 'living organisms' and notes how, in addition to people, they might have many and diverse animal inhabitants. That would certainly have been true for Mesolithic structures with a range of insects, spiders and so forth arriving with the construction materials and the structures being used by rodents and birds, and potentially larger animals, when humans are absent. Such animals "contribute to its [i.e. a house] evolving form, as do the house's human inhabitants in keeping it under repair, decorating it or making structural alterations in response to their changing domestic circumstances ... Building, then, is a process that is continually going on, for as long as people dwell in an environment. It does not begin here with a pre-formed plan, and end there, with a finished artifact." (Ingold 2000, 187).

Intermittent use of the British pit-houses and Criet Dubh, interspersed with long periods of abandonment, with an on-going modification of form arising from human, animal and plant activity, along with physical processes of erosion caused by wind and rain, provides an alternative interpretation to the proposals for continuous occupation, either on a recurrent seasonal basis or from partial/full sedentism as forwarded by Bayliss \& Woodman (2009), Waddington (2007; Waddington \& Bonsall 2016), Gooder (2007) and Robertson et al. (2013).

\section{Were the pit-houses used primarily for social, symbolic and/or ceremonial activity?}

The apparently isolated character of at least some of the British pit-houses might even question whether these structures were constructed for an economic purpose. Bayliss \& Woodman (2009, 121) noted that insufficient attention is paid to "other types of structure" in the Mesolithic, while 
Gooder $(2007,57)$ raised the possibility of huts acting as a symbolic and visible markers expressing rights to land tenure. Waddington et al. (2007) considered, and rejected, the possibility that the Howick structure might have been a sweat lodge or other type of ceremonial structure, but this should be re-visited.

Hunter-gatherers use a wide range of structures for social, ritual and ceremonial purposes, notably sweat lodges (e.g. Gamble 1995; Hyrnick \& Betts 2014; Sutton 2016). The British pit-houses have some of the expected archaeological attributes for sweat-lodges, notably interior hearths with fire cracked stone, and sunken floors (for Howick, Mount Sandel and Echline). Their size suggests comparison to the larger sweat lodges of Native Americans that were designed for ceremonial purposes, such as the 'apayik' rather than the 'uqstilulu' of the Chumas (Sutton 2016). Construction for this purpose might explain the isolated nature of the British pit-houses, assuming that surrounding shelters served the economic and domestic needs of the hunter-gatherer group. Such surrounding activity might be represented by the occupation horizon around the periphery of East Barns (Gooder 2007), the smaller structures at Echline Fields (Robertson et al. 2013) and the range of features outside of the hut/pit-house area at Mount Sandel (Woodman 1985).

Conversely, however, the quantity of artefacts recovered from the interior of Criet Dubh, Howick and Echline suggest something other than sitting, sweating, singing, praying and so forth. One possibility is that these structures were originally constructed as ceremonial centres or territorial markers and were then reused for domestic activities at a later date, possibly when partially collapsed and beyond the memory of their original purpose. This might accord with Waddington's idea of a secondary colonization of Britain: social and ritual activities might have been of particular significance for a pioneer population within an uncertain environment needing to maintain strong social ties, with the need for these being alleviated once the landscape had become familiar and a settlement pattern established.

\section{CONCLUSION}

Criet Dubh adds to the increasing number of sites with both evidence for structures and a robust chronological model. It appears sufficiently different to Mount Sandel, Howick, East Barns, Echline and Cass-ny-Hawin II to sustain the view that these constitute a distinct group of structures chronologically restricted to 8300-7600 cal BC (for initial construction) appropriately described as

pit-houses. We are sympathetic to Waddington's model that such pit-houses first appeared in Britain as part of a cultural package with coastal adaptation and narrow blade technology, representing a secondary colonization of Britain in response to environmental change, notably the inundation of the North Sea basin. Nevertheless, we also note that inferred structures such as Criet Dubh and Broom Hill share features with the pit-houses, and may have appeared significantly more similar had their upper deposits not been so eroded. Also, we note that the chronological separation between the most recent activity events at Howick (7410 cal BC) and Echline (7080 cal BC) are 
closer to the two earliest activity events of Phase 2 at Criet Dubh (7080 cal BC, 6970 cal BC), than they are to the initial activity at Howick and Echline. This suggests that Criet Dubh might have been constructed within the same mode of settlement pattern.

Our consideration suggest three alternative interpretations for the pit-houses and Criet Dubh structure:

Following Gooder (2007), Waddington (2007, 2016; Waddington et al. 2007; Waddington \& Bonsall 2016), Bayliss \& Woodman (2009) and Robertson et al. (2013, 57), these structures reflect "a degree of sedentism or extended residence not traditionally identified with sites of this period" [i.e. the Mesolithic] with various degrees of nuance and caution from each of these authors. This interpretation places most emphasis on the occupation spans as derived from Bayesian analysis of radiocarbon dates, the substantial nature of the structures, the lack of any evident hiatus in occupation from the archaeological deposits at Howick, and the evidence for economic activities.

These structures reflect intermittent occupation within a sparsely populated landscape by mobile hunter-gatherers, re-building dilapidated structures after lengthy periods of abandonment. This interpretation prioritises the activity event approach, notes that archaeological records of partial or full sedentism by hunter-gatherers are considerably more elaborate than that found in the British Mesolithic, draws on ethnographic analogy and places greater emphasis on the long-term formation processes of the archaeological record. In this interpretation, the substantial nature of the pithouses might derive from either (i) original construction for ceremonial purposes by a pioneering population, or (ii) being an artefact of multiple occupations and natural processes during periods of abandoment that have left an archaeological impression of a more substantial structure than would have ever been constructed at a single moment in time.

A combination of (1) and (2): short periods of partial or full sedentism (of the type referred to by Robertson, Gooder, and Waddington et al.) lasting for durations that are contained within the uncertainty limits of a cluster of statistically consistent radiocarbon dates, interspersed with lengthy periods of abandonment of the structure, and possibly the entire landscape. While this prioritises the activity event approach it notes that each 'event' might have lasted for a human generation and attributes the substantial nature of the pit-houses and Criet Dubh, with their domestic debris, to a combination of investment in place for economic purpose and the development of the structures through repeated usage.

While there remains uncertainty over such interpretations, what appears indisputable is that with the new discoveries of structures, the use of multiple radiocarbon determinations, the application of Bayesian analysis, and the ability to connect cultural and environment change, the Mesolithic has become a particularly interesting period of study in British prehistory. 


\section{ACKOWLEDGEMENTS}

The authors are grateful to Billy and Jason Smith for permission to excavate at Criet Dubh and to Historic Environment Scotland for supporting the 2014 rescue excavation and provision of radiocarbon dates. Anne Pirie provided a report on the chipped stone artefacts. Previous work at Criet Dubh was kindly supported by the University of Reading. Elaine Jamieson supported the preparation of this publication. We are grateful to Clive Waddington and Caroline WickhamJones for commenting on an earlier version of this manuscript, and to the comments from three anonymous referees.

\section{BIBLIOGRAPHY}

Bamforth, M., Taylor, M., Taylor, B., Robson, H. K., Radini, A. and Milner, N. 2018. Wooden Structures. In: Milner, N., Conneller, C. and Taylor, B. (eds.) Star Carr Volume 1: A Persistent Place in a Changing World, pp. 69-121. York: White Rose University Press. DOI: https://doi. org/10.22599/book1.f. Licence: CC BY-NC 4.0

Bayliss, A. \& P. Woodman. 2009. A new Bayesian chronology for Mesolithic occupation at Mount Sandel, Northern Ireland. Proceedings of the Prehistoric Society 75, 101-23

Bayliss, A., Taylor, B., Ramsey, C. B., Dunbar, E., Kromer, B., Bamforth, M., Conneller, C., Elliot, B., Knight, B. and Milner, N. 2018. Dating the Archaeology and Environment of the Star Carr Embayment. In: N. Milner, C. Conneller, and B. Taylor (eds.) Star Carr Volume 2: Studies in Technology, Subsistence and Environment, pp. 33-112. York: White Rose University Press. DOI: https://doi.org/10.22599/book2.c. Licence: CC BY-NC 4.0

Binford, L. 1982. The archaeology of place. Journal of Anthropological Archaeology 1, 5-31

Binford, L. 1990. Mobility, housing and environment: A comparative study. Journal of Anthropological Research 46, 119-52

Bridges, E.L. 1947. The Uttermost Part of the Earth. London: Hodder and Stoughton

Bjerck, H. 2007. Mesolithic coastal settlements and shell middens (?) in Norway. In Milner, N., Craig, O.E. and Bailey, G.N. (eds) Shell Middens in Atlantic Europe, 5-31. Oxford: Oxbow Books

Bjerck, K. 2008. Norwegian Mesolithic trends. A review. In G. Bailey \& P. Spikens (eds) Mesolithic Europe, 60-106. Cambridge: Cambridge University Press

Bronk Ramsey, C., 2009. Bayesian analysis of radiocarbon dates, Radiocarbon 51, 337-360

Bronk Ramsey, C., 2011. OxCal v.4.1 Manual, https://c14.arch.ox.ac.uk/oxcal/OxCal.html 
Clark, J. G. D. 1954. Excavations at Star Carr: An Early Mesolithic Site at Seamer near Scarborough, Yorkshire. Cambridge: Cambridge University Press.

Cleal, K., Walker, E. and Montague, R. 1995. Stonehenge in its Landscape: Twentieth century Excavations. London: English Heritage

Coles, J.M. 1971. The early settlement of Scotland: excavations at Morton, Fife. Proceedings of the Prehistoric Society 37, 284-366

Conneller, C., Milner, N., Taylor, B. \& Taylor, M. 2012. Substantial settlement in the European Early Mesolithic: New Research at Star Carr. Antiquity 86, 1004-1020

Cribb, R. 1991. Nomads in Archaeology. Cambridge: Cambridge University Press

Fretheim, S.E. 2017. Mesolithic Dwellings. An Empirical Approach to Past Trends and Present Interpretations in Norway. Thesis for the Degree of Philosophiae. Norwegian University of Science and Technology. Trondhein, Norway

Fretheim, S.E., Bjerck, H.B., Breivik, H.M. \& Zangrando, A.F.J. 2018. Tent, hut or house? A discussion on Early Mesolithic dwelings proceeding from the site Mohalsen 2012-II, Vega, northern Norway. In H.P. Blankholm (ed) The Early Economy and Settlement in Northern EuropePioneering, Resource Use, Coping with Change. United Kingdom: Equinox eBooks Publishing

Fretheim, S.E., Piana, E.L., Bjerck, H.B., \& Zangrando, A.F.J. 2016. Home by the sea - exploring traditions of dwelling reoccupations and settlement stability among marine foragers in Norway and Tierra del Fuego. In H.B. Bjerck, H.M. Breivik, S.E. Fretheim, E.L. Pena, B. Skar, A.M. Tivoli \& A.F.J. Zangrando (eds) Marine Ventures. Archaeological Perspectives on Human-Sea Relations. Proceedings from the Marine Ventures International Symposium in Trondheim 2013, 175-192. Sheffield: Equinox Publishing Ltd

Gaffney, V. et al. 2013. Time and place: A lunar-solar 'time-reckoner from $8^{\text {th }}$ millenniums Scotland. Internet Archaeololgy 34 https://doi.org/10.11141/ia.34.1

Gamble, L. 1995. Chumash architecture: sweat lodges and houses. Journal of California and Great basin Archaeology 17, 54-92

Gardiner, P. 2007. Mesolithic activity at Hawkcombe Head, Somerset: an interim report on the 2002-3 excavations. In C. Waddington and K. L. R. Pedersen (eds) Mesolithic Studies in the North Sea Basin and Beyond. Proceedings of a Conference Held at Newcastle in 2003, 81-95. Oxford: Oxbow Books

Gooder, J. 2007. Excavation of a Mesolithic house at East Barns, East Lothian, Scotland: an Interim Review. In C. Waddington and K. L. R. Pedersen (eds) Mesolithic Studies in the North Sea Basin 
and Beyond. Proceedings of a Conference Held at Newcastle in 2003, 49-60. Oxford, Oxbow Books

Hamilton, D. 2016. Radiocarbon dating and Bayesian modeling. In Waddington, C. \& Bonsall, C. Archaeology and Environment on the North Sea Littoral: A Case Study from Low Hauxley, 82-92. Bakewell, Derbyshire: Archaeological Research Services Ltd

Hrynick, M.G., and M.W. Betts 2014. Identifying Ritual Structures in the Archaeological Record: A Maritime Woodland Period Sweathouse from Nova Scotia, Canada. Journal of Anthropological Archaeology 35, 92-105

Ingold, T. 2000. The Perception of the Environment: Essays on Livelihood, Dwelling and Skill. London: Routledge

Jacques, D., Lyons, T. and Phillips, T. 2017. Blick Mead, exploring the 'first place' in the Stonehenge Landscape. Current Archaeology 324 https://www.archaeology.co.uk/articles/blickmead.htm

Lee, D.H.J. \& Woodward N.L. (orthcoming. Finding the Mesolithic in Orkney: Occupation at Links House, Stronsay, c.7000 cal BC and the first structural evidence for the Northern Isles of Scotland

Lothrop, S.K. 1928. The Indians of Tierra del Fuego. Contributions of the Museum of the American Indians, Washington, DC: Heye Foundation

Kelly, R. 1995. The Foraging Spectrum. Diversity in Hunter-Gatherer Lifeways. Washington: Smithsonian Institution Press

MacGregor, G., Donnelly, M., Miller, S., Ramsay, D. \& Alldrit, T. 2010. A Mesolithic Scatter from Littlehill Bridge, Girvan, Ayrshire. Scottish Archaeological Journal 23, 1-14

McCullagh, R. 1989. Excavation at Newton, Islay. Glasgow Archaeological Journal 23, 1-14

Mellars, P. 1987. Excavations on Oronsay. Edinburgh: Edinburgh University Press

Mellars, P., Schadla-Hall, T., Lane, P. \& Taylor, M. 1998. The wooden platform. In P. Mellars \& P. Dark (eds.), Star Carr in Context: New Archaeological Investigations at the Early Mesolithic site of Star Carr, North Yorkshire, 47-64. Cambridge: McDonald Institute for Archaeological Research.

Milner, N., Conneller, C. and Taylor, B. 2018. Star Carr Volume 1: A Persistent Place in a Changing Landscape. York: White Rose University Press

Mithen, S.J. (ed.) 2000. Hunter-Gatherer Landscape Archaeology: The Southern Hebrides Mesolithic Project 1988-1998. Cambridge: The McDonald Institute for Archaeological Research 
Mithen, S.J. 2003. After the Ice: A Global Human History 20,000-5000 BC. London: Weidenfeld \& Nicolson

Mithen, S.J., Finlay, N., Carruthers, W., Carter, S. \& Ashmore, P. 2001. Plant use in the Mesolithic: evidence from Staosnaig, Isle of Colonsay. Journal of Archaeological Science 28, 223-34

Mithen, S.J. \& Wicks, K. 2011. Inner Hebrides Mesolithic Project (IHMP), Criet Dubh, Isle of Mull. Discovery \& Excavation Scotland 11, 45

Mithen, S.J., Wicks, K, Pirie, A.E., Riede, F., Lane, C., Banjerea, R., Cullen, V., Gittins, M. \& Pankhurst, N. 2015. A late glacial archaeological site and tephra sequence in the far northwest of Europe: Ahrensburgian artefacts and geoarchaeology at Rupha Port an t-Seilich, Isle of Islay, western Scotland. Journal of Quaternary Science 30, 396-416

O’Malley \& Jacobi, 1978. The Excavation of a Mesolithic Occupation Site at Broom Hill, Braishfield, 1971-73. Rescue Archaeology in Hampshire 4, 16-38

Orquera, L., Legoupil, D., and Piana, E.L. 2011. Litoral adaptation at the southern end of South America. Quaternary International 239, 61-69.

Reimer, P.J., Bard, E., Bayliss, A., Beck, J.W., Blackwell, P.G., Bronk Ramsey, C., Grootes, P.M., Guilderson, T.P., Haflidason, H., Hajdas, I., Hatte, C., Heaton, T.J., Hoffmann, D.L., Hogg, A.G., Hughen, K.A., Kaiser, K.F., Kromer, B., Manning, S.W., Niu, M., Reimer, R.W., Richards, D.A., Scott, E.M., Southon, J.R., Staff, R.A., Turney, C.S.M. \& van der Plicht, J., 2013. IntCal13 and Marine13 Radiocarbon Age Calibration Curves 0-50,000 Years cal BP, Radiocarbon 55, 1869-1887

Robertson, A., Lochrie, J. \& Timpany, S. 2013. Built to last: Mesolithic and Neolithic settlement at two sites beside the Forth estuary, Scotland. Proceedings of the Society of Antiquaries of Scotland $143,73-136$

Saville, A. 2004. The material culture of Mesolithic Scotland. In A. Saville (ed.) Mesolithic Scotland and its Neighbours. The Early Holocene Prehistory of Scotland, its British and Irish Context and Some Northern European Perspectives, 185-220. Edinburgh: Society of Antiquaries of Scotland

Saville, A. 2008. The beginning of the later Mesolithic in Scotland. In Z. Sulgostowska, and A.J. Tomaszewski, (eds) Man-Millennia-Environment. Studies in Honour of Romuald Schild, 207-213. Warsaw: Institute of Archaeology and Ethnology Polish Academy of Sciences

Selkirk, A. 1978. Broom Hill, Braishfield. Mesolithic dwelling. Current Archaeology 63, 117-20 
Suddaby, I, 2007. Downsizing in the Mesolithic? The discovery of two associated post-circles at Silvercrest, Lesmurdie Road, Engin, Scotland. In C. Waddington and K. L. R. Pedersen (eds) Mesolithic Studies in the North Sea Basin and Beyond. Proceedings of a Conference Held at Newcastle in 2003, 60-68. Oxford: Oxbow Books

Sutton, E.A. 2016. A possible sweat lodge at the island Chumash village of Nimatala on Limuw, Santa Cruz Island, Alta, Californian. Journal of Californian Archaeology 7, 295-315

Taylor, B., Milner, N. and Conneller, C. 2018. Dryland Structures. In: N. Milner, C. Conneller, and B. Taylor, B. Star Carr Volume 1: A Persistent Place in a Changing World, pp. 57-68. York: White Rose University Press. DOI: https://doi.org/10.22599/book1.e. Licence: CC BY-NC 4.0

Vidal, H.J. 1999. The Yamana of Tierra del Fuego. In R.B. Lee and R. Daly (eds) The Cambridge Encyclopedia of Hunters and Gatherers, 114-118. Cambridge: Cambridge University Press

Waddington, C., 2007. Mesolithic Settlement in the North Sea Basin. A Case Study from Howick, North-East England. Oxford: Oxbow Books

Waddington, C. 2015. Mesolithic re-colonisation of Britain following the drowning of North Sea landscapes. In Ashton, N. and Harris, C. (eds.). No Stone Unturned: Papers in Honour of Roger Jacobi, 221-232. London: Lithic Studies Society

Waddington, C., G. Bailey, A. Bayliss \& N. Milner. 2007. Howick in its North Sea context. In C. Waddington (ed.) Mesolithic Settlement in the North Sea Basin. A Case Study from Howick, NorthEast England, 203-24. Oxford: Oxbow Books

Waddington, C. \& Bonsall, C. 2016. Archaeology and Environment on the North Sea Littoral: A Case Study from Low Hauxley. Bakewell, Derbyshire: Archaeological Research Services Ltd Waddington, C. \& Wicks, K. 2017. Resilience or wipe out? Evaluating the convergent impacts of the $8.2 \mathrm{ka}$ event and Storegga tsunami on the Mesolithic of northeast Britain. Journal of Archaeological Science Reports 14, 692-714

Warren, G., Fraser, S., Clarke, A., Driscoll, K., Mitchell, W., Noble, G., Paterson, D., Schulting, R., Tipping, R., Verbaas, A., Wilson, C. and Wickhma-Jones, C. 2018. Little House in the Mountains? A small Mesolithic structure from the Cairngorm Mountains, Scotland. Journal of Archaeological Science Reports. In press.

Wickham-Jones, C.R. 1990. Rhum: Mesolithic and Later Sites At Kinloch, Excavations 1984-86. Edinburgh: Society of Antiquaries of Scotland, Monograph Series 7

Wickham-Jones, C.R. 2004. Structural evidence in the Scottish Mesolithic. In A. Saville (ed.) Mesolithic Scotland and its Neighbours. The Early Holocene Prehistory of Scotland, its British 
and Irish Context and Some Northern European Perspectives, 229-260. Edinburgh: Society of Antiquaries of Scotland

Wickham-Jones, C.R. and Dalland, M. 1998. A small Mesolithic site at Fife Ness, Fife, Scotland. Internet Archaeology 5, 1-32

Wicks, K. \& Mithen, S.J. 2011. Billy's Garden, the earliest Mesolithic site in Western Scotland. Archaeology Scotland 11, 8-9

Wicks, K. \& Mithen, S. 2014. The impact of the abrupt 8.2 ka cold event on the Mesolithic population of western Scotland: a Bayesian chronological analysis using 'activity events' as a population proxy. Journal of Archaeological Science 45, 240-269

Wicks, K. \& Mithen, S.J. 2017. Economy and environment during the early Mesolithic of western Scotland: Repeated visits to a fishing locality on a small island in the Inner Hebrides. In: P.Persson, E. Reide, B. Skar, H.M.Breivik \& L. Johnson (eds) The Ecology of Early Settlement in Northern Europe: Conditions for Subsistence and Survival (Volume 1), 20-55. Sheffield: Equinox Publishing Ltd

Wood J. 2007. A Mesolithic house, Savecok, Cornwall? From hooves to secret feather pits. In C. Waddington and K. L. R. Pedersen (eds) Mesolithic Studies in the North Sea Basin and Beyond. Proceedings of a Conference Held at Newcastle in 2003, 96-100. Oxford: Oxbow Books

Woodman, P. 1985. Excavations at Mount Sandel, 1973-77. Belfast: HMSO, Northern Ireland Archaeological Monograph 2

Woodman, P. 1987. Excavations at Cass-ny-Hawin, a Manx Mesolithic site, and the position of the Manx microlithic industries. Proceedings of the Prehistoric Society 53, 1-22 